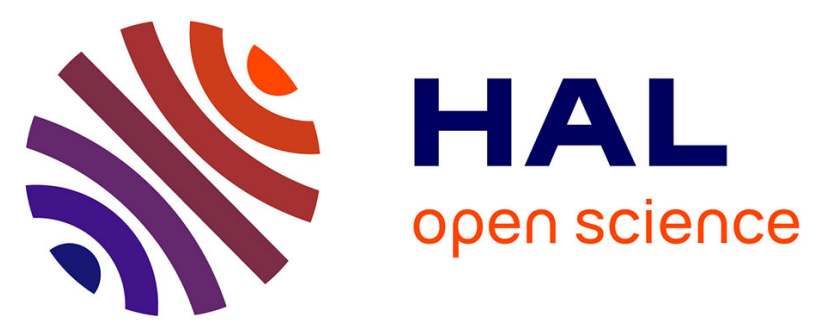

\title{
Evolution of magma decompression and discharge during a Plinian event (Late Bronze-Age eruption, Santorini) from multiple eruption-intensity proxies
}

Madison Myers, Timothy H. Druitt, Federica Schiavi, Lucia Gurioli, Taya Flaherty

\section{To cite this version:}

Madison Myers, Timothy H. Druitt, Federica Schiavi, Lucia Gurioli, Taya Flaherty. Evolution of magma decompression and discharge during a Plinian event (Late Bronze-Age eruption, Santorini) from multiple eruption-intensity proxies. Bulletin of Volcanology, 2021, 83 (3), 10.1007/s00445-02101438-3 . hal-03269773

\author{
HAL Id: hal-03269773 \\ https://hal.uca.fr/hal-03269773
}

Submitted on 22 Nov 2021

HAL is a multi-disciplinary open access archive for the deposit and dissemination of scientific research documents, whether they are published or not. The documents may come from teaching and research institutions in France or abroad, or from public or private research centers.
L'archive ouverte pluridisciplinaire HAL, est destinée au dépôt et à la diffusion de documents scientifiques de niveau recherche, publiés ou non, émanant des établissements d'enseignement et de recherche français ou étrangers, des laboratoires publics ou privés. 
3 Evolution of magma ascent and discharge during a Plinian event

4 (Late Bronze-Age eruption, Santorini) from multiple eruption-

$5 \quad$ intensity proxies

6

7 Madison L. Myers ${ }^{\mathrm{a}, \mathrm{b}}$, Timothy H. Druitt ${ }^{\mathrm{a}}$, Federica Schiavi ${ }^{\mathrm{a}}$, Lucia Gurioli ${ }^{\mathrm{a}}$, and Taya Flaherty ${ }^{\mathrm{a}}$

8

9 a Université Clermont Auvergne, CNRS, IRD, OPGC, Laboratoire Magmas et Volcans, F-63000 Clermont-

10 Ferrand, France

$11{ }^{\mathrm{b}}$ Montana State University, Department of Earth Sciences, Bozeman MT 59717-1272

12

13

14

15

16

17

18

19

20

21 *Corresponding author. Email address: madison.myers@montana.edu 


\section{Abstract}

23 We have coupled three independent methods to investigate the time-evolution of eruptive

24 intensity during the sub-Plinian and Plinian phases of the 3600 y BP Late Bronze Age eruption of

25 Santorini Volcano: (1) mass eruption rate based on new lithic isopleth maps for multiple layers of

26 the fall deposit, (2) magma decompression rate calculated from vesicle number densities, and (3)

27 magma decompression rate calculated from $\mathrm{H}_{2} \mathrm{O}$ gradients in melt reentrants, with methods 2 and

283 measured on the same suite of pyroclasts. Mass eruption rate increased by two orders of

29 magnitude, reaching $210 \times 10^{6} \mathrm{~kg} \mathrm{~s}^{-1}$ at the peak of the Plinian phase (plume height $28.4 \pm 1.0$

$30 \mathrm{~km})$; it then declined in the final stage of fallout emplacement following the first generation of

31 pyroclastic surges. Decompression rates from melt reentrants $\left(0.008\right.$ to $\left.0.25 \mathrm{MPa} \mathrm{s}^{-1}\right)$ are two to

32 three orders of magnitude lower than those from vesicle number densities, assuming heterogeneous

33 vesicle nucleation ( 2 to $19 \mathrm{MPa} \mathrm{s}^{-1}$ ). Melt reentrants probably record slow decompression in the

34 deep feeder conduit, whereas vesicles record much higher rates of decompression in the shallow

35 conduit due to the steep, non-linear pressure gradients associated with magma vesiculation and

36 fragmentation. Upwardly converging flow from a dike-like, deep conduit to a more cylindrical,

37 shallow conduit may also have played a role in causing upwardly accelerating flow. Variations in

38 deep decompression rate recorded by melt reentrants are decoupled from mass eruption rate,

39 whereas those recorded by vesicles lie in between. Taken with the transition from unsteady to

40 steady Plinian eruption conditions, this may reflect the existence of transient flow conditions in

41 the conduit system due to progressing widening and lengthening of a deep feeder dike as Plinian

42 eruption progressed. As the mass eruption rate rose to its peak value, the fragmentation level fell

43 in the conduit due to increasing rates of magma strain and decompression. 
45 Keywords: Plinian eruption, Santorini, decompression rate, conduit development, vesicle number

46 density, melt reentrant

48 Introduction

49 Caldera-forming explosive eruptions are amongst the most devastating natural events on

50 Earth (Mason et al. 2004; Miller and Wark 2008). As more than 500 million people live within

51 the maximum exposure range of a volcano (Doocy et. al 2013), refining techniques to measure

52 how quickly magma moves to the surface, and how magma flow evolves over the course of an

53 eruption, is crucial for improved hazards monitoring and risk mitigation. Determining the

54 processes that control transitions in eruption style, which commonly take place during eruptions

55 due to shifts in external and internal parameters, is also important (Hildreth and Drake 1992;

56 Woods and Koyaguchi 1994; Castro and Gardner 2008; Degruyter et al. 2012). Few silicic

57 caldera-forming eruptions have ever been recorded by modern scientific instrumentation, so

58 understanding of the processes leading up to, and during, such eruptions relies heavily on studies

59 of their erupted products.

60 Three main clast-based techniques are available for estimating magma flow rate from

61 measurements on pyroclastic fall deposits. One uses clast-isopleth data to estimate eruption plume

62 height through application of plume model inversions (Carey and Sparks 1986; Bonadonna and

63 Costa 2013). By splitting the fall deposit into multiple layers, this technique can yield variations

64 of mass eruption rate with time (Sulpizio et al. 2010; Houghton et al. 2014). Decompression rates

65 for particular volcanic episodes can also be determined using individual pyroclasts. For instance,

66 the number density of vesicles generated by ascent-driven nucleation is a function of magma

67 decompression rate (e.g., Klug and Cashman 1996; Mourtada-Bonnefoi and Laporte 2004; 

et al. 2010; Hamada et al. 2010; Martel and Iacono-Marziano 2015; Hajimirza et al. 2019; Nishiwaki and Toramaru 2019), although several processes occur in the conduit (e.g.

71 coalescence, heterogenous nucleation, etc.) that may complicate interpretation. Another approach

72 is to model gradients of dissolved $\mathrm{H}_{2} \mathrm{O}$ and (if present in detectable quantities) $\mathrm{CO}_{2}$ preserved in

73 crystal-hosted melt reentrants to estimate the decompression rate experienced by the crystal during

74 ascent to the surface and prior to eruption quench (Liu et al. 2007; Myers et al. 2016, 2018).

75 Although several studies have investigated the evolution of mass eruption rate with vesicle number

76 density (and calculated decompression rate) through a volcanic sequence, no study has directly

77 compared decompression rates determined using melt reentrants with those using vesicle number

78 density from the same pyroclasts.

79 In this study we compare and contrast all three independent methods during the opening sub-

80 Plinian and Plinian fallout phases of the Late Bronze-Age (LBA) eruption of Santorini (Bond and

81 Sparks 1976; Taddeucci and Wohletz 2001; Druitt 2014). We integrate the results with pre-

82 existing interpretations for how eruptive activity proceeded during these eruptive phases. A major

83 conclusion of our work is that decompression rates recorded by the deep and shallow conduit 84 systems are decoupled, and we propose a possible explanation in the case of the LBA eruption.

\section{Geologic Background}

The Santorini volcanic field is located on the Aegean volcanic arc, within a NE-SW

88 trending rift zone (Fig. 1a). It is the most active volcanic center in the eastern Mediterranean region,

89 having had at least twelve Plinian eruptions over the last $360 \mathrm{ky}$, interspersed with episodes of lava

90 emission and smaller explosive events (Druitt et al. 1999). The-present-day (LBA) caldera is up 
91 to $400 \mathrm{~m}$ deep and is cut by a prominent NE-SW lineament called the Kameni Line, which is

92 parallel to the rift zone (Fig. 1b). Vents of historical volcanic activity are aligned along the Kameni

93 Line, as were epicenters of the seismic unrest of 2011-12 (Kaviris et al. 2015), highlighting that

94 it is a major line of weakness in the caldera.

95 The LBA eruption (also commonly called the Minoan eruption) was the most recent Plinian

96 event at Santorini, occurring $\sim 3600$ years ago. It discharged $48-86 \mathrm{~km}^{3}$ of magma and comminuted

97 rock debris, and collapsed a large part of the modern-day caldera. It began with sub-Plinian

98 precursory explosions, the plumes from which were largely dispersed to the south (phase 0 )

99 (Heiken and McCoy 1990; Cioni et al. 2000). The eruption then evolved through four main

100 phases (Fig. 1c): a Plinian plume (phase 1), pyroclastic surges (phase 2), low-temperature,

101 pyroclastic flows (phase 3), and voluminous hot, fluidized pyroclastic flows (phase 4) (Bond and

102 Sparks 1976; Heiken and McCoy 1984; Sparks and Wilson 1990; Taddeucci and Wohletz

103 2001; Druitt 2014).

104 The vent for phase 1 has been extrapolated to a location on the Kameni Line; the plume

105 was dispersed to the east to south-east and grew with time, producing a reversely graded pumice

106 fall deposit preserved up to $6 \mathrm{~m}$ thick (Bond and Sparks 1976; Heiken and McCoy 1984). The

107 resulting fall deposit has a volume of at least $1-2 \mathrm{~km}^{3}$ dense-rock equivalent, and has been

108 subdivided into four layers, P1a - P1d (Druitt 2014). Layer P1a is crudely stratified and records

109 an initial, unsteady Plinian plume; layer P1b is non-stratified and records a steadier plume. Layer

$110 \mathrm{P} 1 \mathrm{c}$ is a thin pyroclastic surge bed (commonly referred to in previous publications as the

111 'phreatomagmatic break' or 'flow break'); it is overlain by layer P1d, the last fall layer prior to the

112 transition to eruptive phase 2 (Figs. 1c, 2c,d). 
114 these phases are white rhyodacite pumices, microphenocryst-rich andesitic pumices, and (in the

115 upper portion P1b) cauliform andesitic enclaves. Although the rhyodacite pumices account for $>$

$11699 \%$ of all LBA magma erupted, microphenocryst-rich pumices can comprise $40-90 \%$ of the

117 juvenile material in P0 and the lower levels of P1 (see Table 1 from Druitt 2014). The influx of

118 cauliform andesitic enclaves occurs part way up layer P1b, with their size increasing in conjunction

119 with those of the rhyodacitic pumices and lithic clasts. The microphenocryst-rich pumices and

120 cauliform andesitic enclaves are inferred to represent a separate magma intrusion that was

121 intersected during the tapping of the main rhyodacitic reservoir (Druitt 2014). In this study we

122 focus on the rhyodacitic pumices, and the cauliform enclaves and microphenocryst-rich pumices

123 are not considered. Previous work of Wilson and Houghton (1990) noted only a slight decrease

124 in rhyodacitic pumice density $\left(\sim 0.6\right.$ to $\left.\sim 0.5 \mathrm{~kg} / \mathrm{m}^{3}\right)$, and overall consistent vesicularity $(73-82 \%)$,

125 upwards through P1.

126 Lithic components in the LBA fallout units have been interpreted to record changing levels

127 of fragmentation with time (Druitt 2014). Lithics in $\mathrm{P} 0$ and at the base of $\mathrm{P} 1$ are dominated by

128 lavas, inferred to be shallowly derived. About mid-way through P1b the proportion of altered lava

129 lithics increases, and hydrothermally iron-stained blocks of holocrystalline to glass-bearing

130 granitoids appear in abundance (Figs. 1c, 2b). These then increase in size and abundance to the top

131 of P1b, where they account for a third of the lithic assemblage. Following the first pyroclastic

132 surge (P1c), the final fall layer (P1d) is again dominated by fresh lavas. Making the assumption

133 that free lithics are derived from or above the fragmentation level (e.g. Barberi et al. 1989), the

134 data indicate that the magma fragmentation level was shallow during phase P1a, then descended

135 with time, reaching the top of melt-bearing plutonic lithologies towards the end of phase P1b. 
Phase equilibria experiments and melt inclusion volatile contents have constrained the pre-

137 eruptive storage conditions of the $\sim 70$ wt. $\% \mathrm{SiO}_{2}$ rhyodacite to $850-880{ }^{\circ} \mathrm{C}, 100-160 \mathrm{MPa}, 4-5$

138 wt.\% $\mathrm{H}_{2} \mathrm{O}$ and $<200$ ppm $\mathrm{CO}_{2}$ (Cottrell et al. 1999; Cadoux et al. 2014; Druitt et al. 2016;

139 Flaherty et al. 2018).

140

141 Methods

142 We divided the fall deposit into six layers, expanding upon the original four: P0, P1a1,

143 P1a2, P1b1, P1b2, and P1d (Figs. 1c, Fig. 2). Layer P1a1 is defined by two reversely zoned units

144 with the transition to P1a2 marked by a coarsening of grain size (Fig. 2c, d). A thin parting of

145 coarse ash separates layers P1a2 and P1b1, indicating a transient lowering of the eruption plume.

146 The boundary between P1b1 and P1b2 is identified by the first appearance of cauliform andesitic

147 enclaves. The six layers could be traced between multiple sites around the caldera rim. Maximum

148 lithic size and fall layer thickness measurements were made at 43 localities (see Supplementary

149 Table 1) to determine the evolution of plume height, wind direction, and mass eruption rate during

150 phases 0 and 1 , following the methods of Carey and Sparks (1986). For each site, layer thickness

151 was measured at several local sections, and an average was used on the isopach map (Fig. 3).

152 Following the recommendations of Biass and Bonadonna (2011), three dimensions of the five

153 largest lithic clasts from a $1 \mathrm{~m}^{2}$ section were measured for each fall layer, and the mean of these

154 five averaged diameters was used to create a lithic isopleth map (Supplementary Table 1).

155 Thickness and lithic measurements for P0 were presented previously by (Cioni et al. 2000). We

156 use their estimate for phase 0 plume height and convert it to mass eruption rates in the same way

157 as for our phase 1 data (see Table 1). 
159 samples collected from the thick P1b (lower, middle, upper), resulting in eight samples for this

160 study - one in P0 and seven in P1 (Supplementary Table 2). Given the restricted range of pumice

161 vesicularity and densities (Wilson and Houghton 1990), no particular clast density class was

162 targeted. All samples from P1 were analyzed for melt reentrants and vesicle number density from

163 single pumice clasts; P0 pumices are significantly smaller $(<5 \mathrm{~cm})$ than those of $\mathrm{P} 1$ used in this

164 study (6-13 cm: Supplementary Table 2), requiring multiple clasts to be crushed to obtain enough

165 crystals to find melt reentrants. The pumices were scrubbed to remove any adhering ash matrix,

166 and to ensure that microphenocryst-rich pumices were avoided, as they may have had a different

167 decompression history. Effort was made to avoid pumices with strongly elongated vesicles

168 (Taddeucci and Wohletz 2001), which would affect estimation of vesicle number density. For

169 vesicle analysis, we chose to focus on the rim of each pumice clast, as rims are less likely to have

170 been affected by post-fragmentation vesicle growth and coalescence (Thomas et al. 1994; Shea

171 et al. 2010). Vesicle Number Densities from thick sections of pumice rims, were imaged using a

172 Scanning Electron Microscope at image magnifications from $\times 25$ up to $\times 1000$, and then quantified

173 by analyzing six $\times 500$ and two $\times 1000$ images per pumice clast in FOAMS (Shea et al. 2010). The

174 choice of analyzing these two high magnifications serves to focus our counting on the smallest

175 vesicles, which dominate vesicle number density (Houghton et al. 2010). In our calculations we

176 assumed a constant vesicularity of $75 \%$, based upon the relatively homogenous vesicularity data

177 of Wilson and Houghton (1990). Full processing procedures and discussion of error analyses can

178 be found in the Supplementary Material.

179 The remaining portions of each pumice clast were crushed using a mortar and pestle, sieved

180 to 250 - and $500-\mu \mathrm{m}$ size fractions, and picked for plagioclase, clinopyroxene and orthopyroxene. 
181 All selected crystals were coated in vesiculated glass (Supplementary Figure 1). The crystal

182 separates were then submerged in isopropyl alcohol to search for melt reentrants. This method

183 worked well for plagioclase, but for the darker pyroxenes it was commonly necessary to mount

184 the crystals in Crystalbond, slightly polish into their interiors, and use an optical microscope to

185 search for melt reentrants. Plagioclase was found to contain the majority of melt reentrants

186 (perhaps due to the challenge of observing them in the pyroxenes), mostly situated on crystal faces.

187 Due to the requirements of the 1D diffusion code (see below for more information), care was taken

188 to select only those rare melt reentrants with a simple morphology (i.e. no bottle neck, internal

189 vesicles or minerals, multiple tubes, etc.), which would complicate diffusion assumptions

190 (Supplementary Figure 2). We also selected reentrants with a single vesicle at their mouths to

191 ensure efficient diffusive exchange between the reentrant and the degassing, external melt (after

192 Lloyd et al. 2014). Using this criterion, only a few melt reentrants were found per 50-100 crystals,

193 although this was quite variable between layers. Sixteen melt reentrants in total were studied (Fig.

194 4): fourteen in plagioclase, one in orthopyroxene and one in clinopyroxene. All melt reentrants

195 were measured along their lengths (ranging from 80 to $320 \mu \mathrm{m}$ ) for $\mathrm{H}_{2} \mathrm{O}$ and $\mathrm{CO}_{2}$ concentrations

196 using a Thermo-Nicolet Nexus 670 Fourier transform infrared spectrometer (FTIR) interfaced with

197 a Continuum IR microscope at the University of Oregon using a computer-controlled stage. Of

198 these sixteen melt reentrants, five were found to have flat profiles and were not able to be fit using

199 the diffusion model; these reentrants were not further evaluated. Following FTIR analysis at the

200 University of Oregon (FTIR-UO), eight of the eleven melt reentrants were re-analyzed (3 were

201 lost in this process) at the University Clermont Auvergne by FTIR (FTIR-UCA) and Raman

202 spectroscopy (Raman-UCA). This allowed us to evaluate the dependence of modeled 
203 decompression rates on the measured profiles. All methods for these three separate instruments,

204 and detailed transect information, can be found in the Supplementary Material.

205 To model the measured $\mathrm{H}_{2} \mathrm{O}$ diffusion profiles, we applied the 1-D constant decompression

206 model of Myers et al. (2018). This model, based on that of Liu et al. (2007), allows for comparison

207 of the measured and simulated profiles for various decompression rates. The boundary condition

208 at the contact between the host melt and the mouth of the melt reentrant is based on the melt $\mathrm{H}_{2} \mathrm{O}$

209 and $\mathrm{CO}_{2}$ solubility at a given pressure, updated at each decompression step, and is assumed to be

210 in equilibrium with the external melt outside the crystal (Liu et al. 2007; Myers et al. 2016, 2018).

211

212 Results

213 Plume heights and mass eruption rates

214 Isopach and lithic isopleth maps for phase P1 are shown on Fig. 3. The broadening of

215 isopleths upwards in the fall deposit (Fig. 3b-f) records an increase in plume height with time

216 (particularly between P1b1 and P1b2), prior to a decrease in P1d. Wind direction recorded by the

217 isopleths changes from SSE-wards in P1a1 and P1a2, to E-wards in P1b1, to NE-wards in P1b2.

218 Layer P1d appears to have little wind influence on its dispersion. Wind directions recorded by

219 isopach maps of the same levels agree with those for the isopleths for P1a, but disagree for P1b,

220 where isopach wind directions are less rotated than those indicated by the isopleths (Fig. 3a vs. g).

221 This could be due to the fact that each fallout layer is integrating an overall increase in eruption

222 intensity throughout its thickness, so that the upper portion of the layer is probably where the

223 largest clasts reside. Essentially, where the isopleths are recording the wind direction of the upper

224 portion of any given layer, the isopach thickness is averaging the wind direction of that entire layer. 
226 model (Table 1 and Fig. 5). As the height estimate is based solely on the crosswind range (half

227 width of the depositional envelope), uncertainties presented for plume height are based on the

228 'wiggle-room' available in the crosswind range isopleth placement (Fig. 3). Conversion of isopleth

229 data to plume height used the $3.2 \mathrm{~cm}$ contour, the only one available for all five layers, although

230 this is loosely constrained for P1a1 and P1a2 (Fig. 3). Plume height estimates were also made for

231 the few other isopleths available, however agreement is typically poor between conversions

232 (Supplementary Figures 3 and 4). Although it is feasible to take an average plume height based on

233 several isopleths, because this can only be completed for certain layers, with quality of isopleths

234 not all being equal, we have chosen to focus our interpretations on the $3.2 \mathrm{~cm}$ isopleth. Taking 8.5

$235 \pm 1.5 \mathrm{~km}$ as the estimated plume height for P0 (Cioni et al. 2000), the $3.2 \mathrm{~cm}$ isopleths suggest an

236 initial increase in plume height, with the greatest height of $28.4 \pm 1.0 \mathrm{~km}$ reached in $\mathrm{P} 1 \mathrm{~b} 2$,

237 decreasing to $21.7 \pm 1.1 \mathrm{~km}$ in P1d, following initial pyroclastic surge (P1c) production (Fig. 5,

238 Supplemental Figure 4).

239 Plume heights were converted to mass eruption rate using the methods of Wilson and

240 Walker (1987) and Mastin et al. (2009), yielding values of $1.7 \times 10^{6}$ to $2.1 \times 10^{8} \mathrm{~kg} \mathrm{~s}^{-1}$ and $1.0 \times$

$24110^{6}$ to $1.5 \times 10^{8} \mathrm{~kg} \mathrm{~s}^{-1}$, respectively (Table 1). Error bars associated with the Wilson and Walker

242 (1987) estimates are propagated based on those determined for each plume height (Table 1).

243 Although the conversion based on the Wilson and Walker (1987) formula is consistently higher,

244 it falls within error of the Mastin et al. (2009) value (Table 1). Importantly, the relative range of

245 two orders of magnitude represented by P0 and P1 is consistent between the two methods. The

246 lowest mass eruption rate is associated with P0, and the highest with P1b2 (Fig. 5). 
Visually there is a noticeable change in the sizes of vesicles in the rims of pumice clasts up

250 through P0 and P1, with smaller (average diameter 4-5 $\mu \mathrm{m}$ ) vesicles found at the top of P1a and

251 the top of P1b (Fig. 6, Table 2). The largest vesicles, with average diameters of 9-13 $\mu \mathrm{m}$, are

252 observed in P0 (largest), at the base of P1a, at the base of P1b, and in P1d. Pumice-rim vesicle

253 number density values span 1.5 orders of magnitude, from $2.50 \times 10^{6}$ to $6.56 \times 10^{7} \mathrm{~mm}^{-3}$, falling

254 within the range typical for explosive rhyolitic eruptions (Giachetti et al. 2010; Houghton et al.

255 2010). The lowest vesicle number density is from $P 0$, and the highest is from $\mathrm{P} 1 \mathrm{~b} 2$.

256 Vesicle number densities were converted to decompression rates using equation (2) from

257 Toramaru (2006). This requires estimates of the interfacial tension between $\mathrm{H}_{2} \mathrm{O}$ and melt, the

258 starting saturation pressure and temperature, and the melt $\mathrm{H}_{2} \mathrm{O}$ diffusivity, where the largest

259 uncertainty comes from the choice of interfacial tension (Shea 2017). Using a temperature

$260\left(850^{\circ} \mathrm{C}\right)$, pressure (165 MPa) and $\mathrm{H}_{2} \mathrm{O}$ content (5.2 wt.\%) appropriate for the LBA magma (Druitt

261 et al. 2016; Flaherty et al. 2018), the diffusivity of $\mathrm{H}_{2} \mathrm{O}$ is found to be $1.1 \times 10^{-11} \mathrm{~m}^{2} \mathrm{~s}^{-1}$ (equation

26227 from Zhang et al. 2007). The only remaining unknown is the interfacial tension, which relies

263 on whether vesicle nucleation was homogenous or heterogeneous. We estimate decompression

264 rates using both nucleation mechanisms, where the interfacial tension is taken to be $0.025 \mathrm{~N} \mathrm{~m}^{-1}$

265 and $0.12 \mathrm{~N} \mathrm{~m}^{-1}$ for heterogeneous and homogeneous nucleation, respectively (Shea 2017).

266 Resulting decompression rates recorded by the vesicle number densities are 2-19 MPa s $\mathrm{s}^{-1}$

267 (heterogeneous) or 50-450 $\mathrm{MPa} \mathrm{s}^{-1}$ (homogeneous). In each case, the lowest rate is from P0 and

268 the highest is from P1b2 (Fig. 5).

269

270 Melt Reentrant Volatile Profiles 
Of a total of eleven measured $\mathrm{H}_{2} \mathrm{O}$ profiles in melt reentrants, nine display gradual

272 decreases in $\mathrm{H}_{2} \mathrm{O}$ concentration as the transect approaches the crystal rim and the remaining two

273 preserve slightly flatter profiles (Supplementary Figure 5). Some variabilities in $\mathrm{H}_{2} \mathrm{O}$

274 concentrations and gradients are observed between the three instruments used (FTIR-UO, FTIR-

275 UCA, Raman-UCA), but the shape of each diffusion profile is usually similar (Fig. 7,

276 Supplementary Table 4). Most melt reentrants measured by FTIR spectroscopy contain interior

$277 \mathrm{H}_{2} \mathrm{O}$ concentrations $\left(\mathrm{H}_{2} \mathrm{O}=2.0-5.0 \mathrm{wt} . \%\right)$ lower than those found in isolated melt inclusions in the

278 same phenocryst phases $\left(\mathrm{H}_{2} \mathrm{O}=4.0-5.4\right.$ wt.\%, Table 2 of Druitt et al. 2016); however, some $\mathrm{H}_{2} \mathrm{O}$

279 concentrations determined by Raman spectroscopy $\left(\mathrm{H}_{2} \mathrm{O}=3.2-5.9\right.$ wt.\%) are higher than those

280 found by FTIR. The absence of detectable $\mathrm{CO}_{2}$ in the melt reentrants is not surprising given the

281 low concentrations of $\mathrm{CO}_{2}$ in isolated melt inclusions ( $<200$ ppm; Druitt et al. 2016) and 282 compared to other silicic systems (Myers et al. 2018).

283 All 1-D decompression models requires an estimate of the starting pressure, initial 284 dissolved $\mathrm{H}_{2} \mathrm{O}$ concentration, temperature, and exsolved gas content. Models were run assuming 285 a pre-eruptive temperature of $850^{\circ} \mathrm{C}$, a constant decompression rate and isothermal conditions. A 286 starting pressure (165 MPa) and $\mathrm{H}_{2} \mathrm{O}$ concentration (5.2 wt.\%) were determined based on the lack 287 of measurable $\mathrm{CO}_{2}$, but relatively high $\mathrm{H}_{2} \mathrm{O}$, measured in the interiors of most melt reentrants. This 288 pressure is broadly consistent with that estimated from melt inclusions (100-160 MPa), with $\mathrm{H}_{2} \mathrm{O}$ 289 concentrations representing upper end values measured from melt inclusions, but with $\mathrm{CO}_{2}$ at the 290 lower end of the dataset (Druitt et al. 2016). To objectively choose the best-fit profile, we used 291 an iterative grid-search function to optimize fitting of the measured profiles (Myers et al. 2018).

292 Unlike in Myers et al. (2018), we cycled through a range of decompression rates and 293 fragmentation pressures (pressure where diffusion ceases in the model), rather than initial gas 
294 content. This allowed us to test whether the selected best-fit fragmentation pressure shifts with

295 time during eruption. For low- $\mathrm{CO}_{2}$ systems, the selected decompression rate is less sensitive to

296 starting gas content, so we assumed no initial exsolved gas phase.

297 It was found that for those melt reentrants where concentration profiles were measured by

298 all three methods (eight of eleven), modeled decompression rates were fairly consistent (Fig. 5;

299 Supplementary Figure 5). Good model fits for all profiles could be achieved using our pre-ascent

300 storage pressure estimate of $165 \mathrm{MPa}$. Hereon, we focus on the decompression results based on

301 the University of Oregon FTIR, where all eleven melt reentrants were measured. The resulting

302 decompression rates range between 0.008 and $0.25 \mathrm{MPa} \mathrm{s}^{-1}$, but without any systematic variation

303 with stratigraphic height (Fig. 5). For those layers where multiple melt reentrants were measured

304 and modeled (RDP18, RDP13 and RDP5) agreement between the different decompression rate

305 estimates is good, especially compared to the two orders of magnitude represented by the entire 306 dataset (Fig. 5).

308 Discussion

309 Time variations in plume height and mass eruption rate

310 Our isopleth data indicate that the plume rose from P0 to P1b, before diminishing in height

311 after production of the pyroclastic surges of P1c (Fig. 5). Previous estimates placed the maximum

312 plume height for phase 1 at $36 \pm 5 \mathrm{~km}$, with a maximum eruption rate of $1.4-4.2 \times 10^{8} \mathrm{~kg} \mathrm{~s}^{-1}$

313 (Sigurdsson et al. 1990, Sparks and Wilson 1990, based on the data of Bond and Sparks 1976).

314 Our estimate of maximum plume height is lower than this (layer P1b2: plume height $28.4 \pm 1.0$

$315 \mathrm{~km}$, mass eruption rate $2.1 \pm 0.6 \times 10^{8} \mathrm{~kg} \mathrm{~s}^{-1}$ based on Wilson and Walker 1987), probably because 
316 we restricted sampling to a $1 \mathrm{~m}^{2}$ area, whereas Bond and Sparks (1976) sampled over the entire

317 outcrop (R.S.J. Sparks, written communication).

319 Comparison of the decompression rate estimates

320 Calculated magma decompression rates based on vesicle number density differ by more

321 than an order of magnitude, depending on the nucleation assumption (2-19 MPa s${ }^{-1}$ - heterogeneous

322 or $50-450 \mathrm{MPa} \mathrm{s}^{-1}$ - homogeneous; Fig. 5). Homogenous nucleation is commonly assumed to

323 dominate in more evolved melts (Mangan and Sisson 2000) since silicate minerals are thought to

324 be poor nucleation sites for vesicles (Hurwitz and Navon 1994). Much of the requirement for

325 heterogenous nucleation is based on the presence of Fe-Ti oxides, long established as the best

326 nucleation site for vesicles (Hurwitz and Navon 1994). However, a review of vesicle size

327 distributions and magma decompression rates by Shea (2017) demonstrates that the assumption of

328 homogenous nucleation, and the resulting interfacial tension value, produces decompression

329 estimates that are inconsistent with other nucleation-based rate-meters, and often requires

330 overpressures greater than the inferred depth of storage. Shea (2017) argues that heterogenous

331 nucleation is likely in all magmas (basaltic through rhyolitic), perhaps facilitated by oxide

332 nanolites. The following lines of evidence suggest that heterogenous nucleation occurred during

333 ascent of the LBA magma: (1) $\mathrm{H}_{2} \mathrm{O}$ gradients measured in reentrants can be modeled by constant

334 decompression from the storage region to the fragmentation level, requiring that diffusion to a

335 degassing external melt was occurring early on in magma ascent (and hence that the external melt

336 was growing vesicles); (2) apparent nucleation of vesicles on Fe-Ti oxide grains contained within

337 melt reentrants (Supplementary Figure 2 - not evaluated for $\mathrm{H}_{2} \mathrm{O}$ profiles/decompression rate). 
Even assuming heterogeneous nucleation, the decompression rates from melt reentrants

339 (0.008 to $0.25 \mathrm{MPa} \mathrm{s}^{-1}$, average $\left.0.06 \mathrm{MPa} \mathrm{s}^{-1}\right)$ are 2-3 orders of magnitude lower than those based

340 on vesicle number density (2-19 $\left.\mathrm{MPa} \mathrm{s}^{-1}\right)$, although they each span about an order of magnitude.

341 Previous workers have also noted discrepancies between the rates retrieved from melt reentrants

342 and those from vesicles (Shea 2017; Cassidy et al. 2018). The offset can be understood by

343 considering the kinetics of the two processes. While vesicles nucleate on timescales of seconds in

344 response to rapid magma decompression (e.g., Toramaru 2006; Hajimirza et al. 2019;

345 Nishiwaki and Toramaru 2019), the ability of a $\mathrm{H}_{2} \mathrm{O}$ gradient in a melt reentrant to react to

346 external decompression is limited by the rate of $\mathrm{H}_{2} \mathrm{O}$ diffusion in melt. Melt reentrants will cease

347 recording diffusive $\mathrm{H}_{2} \mathrm{O}$ loss if the magma decompression rate becomes too fast. Liu et al. (2007)

348 estimate this threshold to be $\sim 0.25 \mathrm{MPa} \mathrm{s}^{-1}$ in silicic systems, which indeed corresponds to the

349 uppermost decompression rates reported here and by Myers et al. (2018). While melt reentrants

350 are unable to record decompression rates much higher than this value, vesicle number densities

351 can record much faster rates (Shea 2017). The offset in decompression rates estimated by the two

352 methods suggests that the decompression rate of the magma increased during ascent, from $<0.25$

353 (recorded by melt reentrants) to $>>0.25 \mathrm{MPa} \mathrm{s}^{-1}$ (recorded by vesicles). We envisage two possible

354 explanations, distinguishing between deeper and shallower levels of the feeder conduit.

355

356 1. Nonlinear pressure gradient during ascent to the fragmentation level. As the magma

357 ascends the feeder conduit, water diffuses from the melt to vesicles and the magma

358 vesiculates. The mixture of gas and melt is then accelerated to the surface and undergoes

359 fragmentation. During this process the magma can experience rapidly accelerating

360 decompression due to: (1) increasing gas fraction as the magma degasses and the gas phase 
expands (i.e., mass continuity); (2) large (>> lithostatic) nonlinear pressure gradients

362 immediately beneath the fragmentation level due to the marked increase in melt viscosity

363 as the dissolved water content decreases (Cashman and Scheu 2015; Gonnerman, 2015)

364 (as a silicic melt with $5 \mathrm{wt} . \%$ water degasses to $1 \mathrm{wt} . \%$ water, its viscosity increases by 2 -

3653 orders of magnitude (Giordano et al. 2008; Romine and Whittington 2015); (3) rapid

366 decompression associated with magma fragmentation. The high rates of magma

367 decompression preceding, and accompanying, fragmentation may in some cases trigger a

368 second vesicle nucleation event (Massol and Koyaguchi 2005; Toramaru 2006;

$369 \quad$ Hamada et al. 2010; Hajimirza et al. 2019).

370

371 2. Upwardly converging magma flow. Accelerating magma flow may also result from

372 changes in conduit geometry with depth beneath the volcano, for example a feeder dike at

373 depth focusing upwards into a narrow, shallow conduit. Syn-eruptive magma flow through

374 a deep, dike-shaped conduit transitioning into a shallow cylindrical conduit has been called

375 upon at a number of volcanoes, such as Montserrat in the Antilles (Costa et al. 2007) and

376 Somma-Vesuvius in Italy (Massaro et al. 2018). The location of the vents of LBA phases

377 P0 and P1 on the NE-SW-trending Kameni Line (Fig. 1b), a long-lived line of weakness in

378 Santorini caldera, suggests that it is possible that the LBA magma left its upper crustal

379 reservoir in a dike, then converged into a more cylindrical conduit at shallow levels. This

380 is also inferred to have occurred during historical activity at Santorini (Pyle and Elliott

381 2006, Fig. 8). The upward focusing of magma flow from a $2 \mathrm{~km}$-long dike (the deep

382 conduit) into a $20 \mathrm{~m}$-long segment of that dike (the shallow conduit) could have increased

383 the ascent rate of the LBA magma by two orders of magnitude, providing another possible 
explanation of the offset between melt reentrants and vesicle number density. In this mechanism, the LBA melt reentrants would record the initial slow stage of magma ascent through the deeper feeder dike, and vesicle number density the much faster stage of focused magma flow through the shallow conduit.

390 recorded by melt reentrants and vesicles can be attributed to the non-linear pressure gradient

391 associated with the fragmentation level, possibly coupled with a downward flaring of the feeder

392 conduit. Since melt reentrants only record slower decompression conditions $\left(<0.25 \mathrm{MPa} \mathrm{s}^{-1}\right)$, they

393 likely record flow during deeper magma ascent, whereas vesicle number densities are weighted

394 towards the rapid, nonlinear decompression of faster, shallow ascent associated with fragmentation

395 (Fig. 8; Massol and Koyaguchi 2005; Toramaru 2006; Hamada et al. 2010; Hajimirza et al. 396 2019).

\section{Integration of the different parameter sets}

399 We now compare time variations of the different eruption intensity proxies (Fig. 5). Mass

400 eruption rate is lowest in $\mathrm{P} 0$ and rises steadily to a maximum near the top of $\mathrm{P} 1 \mathrm{~b}$, before decreasing

401 in P1d. Decompression rate from vesicle number density mimics mass eruption rate by increasing 402 from $\mathrm{P} 0$ to $\mathrm{P} 1 \mathrm{a} 2$, being highest at the top of P1b2, then decreasing in P1d. However, it differs from 403 mass eruption rate in that it shows a small drop from P1a2 to P1b1. Finally, decompression rate 404 from melt reentrants increases from P0 to P1a1, then decreases markedly into P1a2 and P1b1 405 before rising again. Time-variations of the three parameters suggests: (1) magma decompression 406 rate in the deep conduit (recorded by melt reentrants) is decoupled from mass eruption rate at the 
407 surface; (2) vesicles record rates intermediate between that in the deep conduit and the mass

408 eruption rate; and (3) changes in decompression rate in the shallow conduit appear to lag behind

409 those in the deep conduit (for example, the drop in decompression rate from P1a1 to P1a2 in the

410 deep conduit occurs in vesicle number density from P1a2 to P1b1; Fig. 5).

411 The observed decoupling between the deep and shallow levels of the conduit may be

412 understood if the deep conduit was a dike, as discussed earlier (Fig. 8). In eruptions fed by dikes

413 that transition into shallow cylindrical conduits, significant decoupling of the two levels of the

414 feeder system are possible (Costa et al. 2007; Massaro et al. 2018). The dike can act as a

415 magmatic capacitor, storing magma (and pressure) by elastic deformation of the dike walls before

416 conveying it to the fragmentation level in the shallow cylindrical conduit. The shallow conduit,

417 generated by vent erosion, in turn modulates the mass eruption rate. Abrupt changes in deep

418 conduit conditions can cause transient flow states, which, due to the high viscosities of silicic melts,

419 can take several hours to propagate up into the shallow conduit (de' Michieli Vitturi et al. 2010).

420 Such effects may explain why time-variations in our shallow (vesicle number density-derived)

421 decompression rate appear to be intermediate between the deep (melt reentrant-derived)

422 decompression rate and the mass eruption rate.

423 It is unclear what could have caused magma ascent rate in the feeder dike to drop by over

424 an order of magnitude during P1a1 and P1b1. Assuming that the data are representative of the

425 magma as a whole, one possibility is that the melt reentrants are recording short-term fluctuations

426 in deep magma decompression rate not captured by the mass eruption rate data. While mass

427 eruption data are layer-averaged, melt reentrants are derived from individual magma parcels

428 (pyroclasts) and may record processes taking place on shorter timescales. The bedded nature of

429 P1a shows that eruptive conditions early on in phase 1 were unsteady, and that quasi-steady 
430 conditions were not attained until P1b. The occurrence of a coarse-ash parting at the P1a-P1b

431 boundary (Figs. 1c, 2c,d) suggests that the mass eruption rate declined greatly at this point in the

432 eruption, as supported by the decrease in decompression rate preserved by melt reentrants and

433 VND, although not shown by our isopleth data. This suggests that melt reentrants and vesicles,

434 due to their ability to respond rapidly to changing decompression conditions (although on subtly

435 different timeframes), may record changes in eruption history that might not be recognized as

436 significant time breaks in the field. The low decompression rates recorded by melt reentrants in

437 P1a2 and at the base of P1b may therefore be inherited from early unsteadiness in deep magma

438 flow as the conduit geometry evolved in response to changes in magma pressure and crustal

439 stresses. Early transient flow and eruption unsteadiness might have been due to widening and

440 lengthening of the deep feeder dyke as the eruption gained pace, as also invoked for the Pomici di

441 Avellino eruption of Vesuvius (Massaro et al. 2018).

443 Behavior of the fragmentation level

444 Magma fragmentation rate is controlled by a number of factors, including magma 445 composition, volatile content, rheology, decompression rate, and strain rate (Cashman and Scheu

446 2015; Gonnerman, 2015, Cassidy et al. 2018 and references therein). The parameter variations

447 in Figure 5 offer a possible explanation for the fall in fragmentation level during P1b, as was

448 inferred from lithic data (Druitt 2014). This idea is supported by high mouth pressures preserved

449 by melt reentrants at the P1b2 level (80-90 MPa; Supplementary Figure 6). Vertical migration of

450 the fragmentation level will depend on the competition between the fragmentation rate and the rate

451 of supply of magma from depth. Neither magma composition, dissolved volatile content, nor

452 rheology changed significantly during the eruption (Flaherty et al. 2018). Thus, the main process 
453 causing the fragmentation level to fall throughout P1b was likely the increasing magma flow rate

454 in the shallow conduit. This could have increased the fragmentation rate by increasing the rates of

455 strain, decompression and development of gas overpressure in vesicles (Gonnerman 2015).

456 Indeed, the number of free crystals (relative to magma crystal content) increase upwards in fall

457 unit P1b, which when coupled with analysis of particle populations, is consistent with increasing

458 fragmentation rate during Plinian eruption prior to phase P1c (Taddeucci and Wohletz 2001).

459 However, the apparent decline in magma supply from the deep feeder dyke early on during P1b

460 (recorded by melt reentrants) may have also played a role by starving the fragmentation level of

461 ascending magma. Once the fragmentation level had dropped significantly in P1b, access of

462 seawater to the conduit, and/or the onset of plume instabilities, caused pyroclastic surge production

463 (P1c). This was then followed by re-establishment of shallow fragmentation (inferred by lithics)

464 and Plinian phase P1d.

465

Rapid Exploitation of a Pre-existing Conduit System

467 Previous work on the opening phases of large rhyolitic eruptions (Huckleberry Ridge,

468 Oruanui and Bishop caldera-forming eruptions) found that melt reentrant diffusion profiles

469 recorded at least a two-stage decompression history: (1) an initial stage of slow decompression

470 prior to (2) a final, faster ascent associated with the explosive eruption (Myers et al. 2018). This

471 explanation was required because measured diffusion profiles in crystals from the opening phases

472 were best recreated using starting volatile concentrations lower than the pre-eruptive magma

473 storage concentrations recorded by isolated melt inclusions. However, as the eruptions progressed

474 (most notably the Bishop Tuff), the modeled starting conditions started to approach the storage

475 concentrations, probably due to a transition from an initial, sluggish ascent to a fully developed 
476 feeder system. These observations, however, are not applicable to the LBA eruption, where all

477 melt reentrant profiles can be reproduced using pre-eruptive storage depth as the initial condition,

478 even in phase 0 (albeit assuming low $\mathrm{CO}_{2}$ ). This could suggest that either feeder development was

479 relatively rapid in the LBA system, or that the ascending magma exploited a pre-existing zone of 480 weakness.

481 Relevant to this idea is that alongside the eruption of the main rhyodacitic LBA magma, 482 phases 0 and 1 were accompanied by a chemically and mineralogically distinct magma (preserved 483 as microphenocryst-rich pumices) that has been interpreted previously to represent an intrusion

484 already present beneath the Plinian vent prior to the LBA eruption (see Druitt 2014 for full data 485 and interpretations); indeed this other magma accounts for up to $40 \%$ of pumice discharged during

486 phase 0 . It is therefore likely that the LBA magma exploited an already existing intrusion to reach 487 the surface, pushing out some of its contents. Furthermore, seismic tomography has imaged a 488 vertical cylinder of low-density rock beneath Santorini caldera extended down to $3 \mathrm{~km}$, which may 489 also suggest the existence of a long-lived structural pathway that could have been exploited by the 490 ascending LBA magma (Hooft et al. 2019).

491

\section{Conclusions}

493 We have compared and contrasted three eruption intensity proxies for the sub-Plinian and Plinian 494 opening phases of the Late Bronze-Age eruption of Santorini: plume height and mass eruption rate 495 from lithic isopleths, magma decompression rate from pumice vesicle number densities, and 496 magma decompression rate from $\mathrm{H}_{2} \mathrm{O}$ diffusion gradients in crystal-hosted melt reentrants. The 497 two decompression-rates determinations were carried out on the same suite of pyroclasts. The aim 
498 was to obtain insight into what each technique records and detail the processes of conduit magma

499 flow early on in a caldera-forming eruption. The main conclusions are as follows.

500 1. Plume heights during fallout accumulation increased from $8.5 \pm 1.5 \mathrm{~km}$ to $28.4 \pm 1 \mathrm{~km}$, 501 then decreased to $21.7 \pm 1.1 \mathrm{~km}$ following a transient phase of pyroclastic surge 502 emplacement. Mass eruption rate during the fallout phases is estimated to have reached $503 \quad 210 \times 10^{6} \mathrm{~kg} \mathrm{~s}^{-1}$.

504 2. Decompression rates estimated from vesicle number densities are 2-3 orders of magnitude 505 higher than those from melt reentrant $\mathrm{H}_{2} \mathrm{O}$ diffusion gradients $\left(0.008\right.$ to $\left.0.25 \mathrm{MPa} \mathrm{s}^{-1}\right)$ if 506 heterogeneous vesicle nucleation is assumed $\left(2-19 \mathrm{MPa} \mathrm{s}^{-1}\right)$, and 4 orders of magnitude 507 higher if homogeneous nucleation is assumed (50-450 MPa s$\left.{ }^{-1}\right)$. Whereas melt reentrants 508 record slow $\left(<0.25 \mathrm{MPa} \mathrm{s}^{-1}\right)$ magma decompression during flow deep in the conduit, vesicle 509 number densities record much higher rates of decompression in the shallow conduit, 510 probably due to the steep, non-linear pressure gradients associated with magma 511 fragmentation. Convergent flow from a dike-shaped deep conduit to a more cylindrical 512 shallow conduit may also in part explain the high rates of magma decompression recorded 513 by vesicles. The two methods therefore provide information on syn-eruptive magma 514 decompression rates at different levels in the conduit.

5153 . The time-variation of magma decompression rate in the deep conduit (recorded by melt 516 reentrants) is decoupled from mass eruption rate at the surface, whereas that in the shallow 517 conduit (recorded by vesicles) lies in between. Changes in shallow decompression rate 518 appear to lag behind those in deep decompression rate. A decrease in decompression rate 519 preserved by melt reentrants during the transition from unsteady to steady flow may have 
resulted from transient flow phenomena in a deep feeder dike, possibly caused by an event

521 of dike widening and/or lengthening.

522 4. Peak eruptive conditions during the Plinian phase were preceded by a fall in the

523 fragmentation level, perhaps due to the increasing rates of shallow magma decompression

524 and strain causing the rate of magma fragmentation to exceed that of magma supply from

525 deeper in the conduit.

526 5. Melt reentrants and vesicles, due to their ability to respond rapidly to changing

527 decompression conditions, may record changes in eruption history that might not be

528 recognized as significant time breaks in the field.

5296 6. The data support a previously published interpretation that the LBA magma made its way

530 to the surface through a pre-existing zone of weakness, likely associated with an intrusion

531 related to an earlier phase of magma movement.

\section{Acknowledgements}

534 The authors would like to thank Bruce Houghton for conversations surrounding isopleth/isopach

535 data, and helpful reviews by the editor, one anonymous reviewer and Alessandro Vona that led to

536 an improved manuscript. This work was funded through a Clermont Auvergne University

537 Postdoctoral grant to Druitt and an NSF grant EAR-1922513 to Myers. We thank Christophe

538 Constantin for thin sections, Jean-Marc Hénot for assistance with the SEM, and Erica Duncan,

539 Emma Kerins, Megan Saalfeld, and Crystal Christensen for processing SEM images. This is

540 Laboratory of Excellence ClerVolc Contribution Number 448.

541

542 References 
Barberi F, Cioni R, Rosi M, et al (1989) Magmatic and phreatomagmatic phases in explosive eruptions of Vesuvius as deduced by grain-size and component analysis of the pyroclastic deposits. J Volcanol Geotherm Res 38:287-307. https://doi.org/10.1016/0377-

547 Biass S, Bonadonna C (2011) A quantitative uncertainty assessment of eruptive parameters

Bonadonna C, Costa A (2013) Plume height, volume, and classification of explosive volcanic derived from tephra deposits: the example of two large eruptions of Cotopaxi volcano, Ecuador. Bull Volcanol 73:73-90. https://doi.org/10.1007/s00445-010-0404-5 eruptions based on the Weibull function. Bull Volcanol 75:742. https://doi.org/10.1007/s00445-013-0742-1

Bond A, Sparks RSJ (1976) The Minoan eruption of Santorini, Greece. J Geol Soc 132:1-16. https://doi.org/10.1144/gsjgs.132.1.0001

Cadoux A, Scaillet B, Druitt TH, Deloule E (2014) Magma Storage Conditions of Large Plinian Eruptions of Santorini Volcano (Greece). J Petrol 55:1129-1171. https://doi.org/10.1093/petrology/egu021

Carey S, Sparks RSJ (1986) Quantitative models of the fallout and dispersal of tephra from volcanic eruption columns. Bull Volcanol 48:109-125. https://doi.org/10.1007/BF01046546

563 Cassidy M, Manga M, Cashman K, Bachmann O (2018) Controls on explosive-effusive volcanic

Cashman KV, Scheu B (2015) Magmatic fragmentation. The encyclopedia of volcanoes (pp. 459-471). Academic Press. eruption styles. Nat Commun 9:2839. https://doi.org/10.1038/s41467-018-05293-3

Castro JM, Gardner JE (2008) Did magma ascent rate control the explosive-effusive transition at the Inyo volcanic chain, California. Geology 36:279. https://doi.org/10.1130/G24453A.1

Cioni R, Gurioli L, Sbrana A, Vougioukalakis G (2000) Precursory phenomena and destructive events related to the Late Bronze Age Minoan (Thera, Greece) and AD 79 (Vesuvius, Italy) Plinian eruptions; inferences from the stratigraphy in the archaeological areas. Geol Soc Lond Spec Publ 171:123-141. https://doi.org/10.1144/GSL.SP.2000.171.01.11

Cluzel N, Laporte D, Provost A, Kannewischer I (2008) Kinetics of heterogeneous bubble nucleation in rhyolitic melts: implications for the number density of bubbles in volcanic conduits and for pumice textures. Contrib Mineral Petrol 156:745-763. https://doi.org/10.1007/s00410-008-0313-1

Costa A, Melnik O, Sparks RSJ, Voight B (2007) Control of magma flow in dykes on cyclic lava dome extrusion. Geophys Res Lett 34:L02303. https://doi.org/10.1029/2006GL027466 
577

578

579

580

581

582

583

584

585

586

587

588

589

590

591

592

593

594

595

596

597

598

599

600

601

602

603

604

605

606

607

608

609

610

611

612

Cottrell E, Gardner JE, Rutherford MJ (1999) Petrologic and experimental evidence for the movement and heating of the pre-eruptive Minoan rhyodacite (Santorini, Greece). Contrib Mineral Petrol 135:315-331. https://doi.org/10.1007/s004100050514

de' Michieli Vitturi M, Clarke AB, Neri A, Voight B (2010) Transient effects of magma ascent dynamics along a geometrically variable dome-feeding conduit. Earth Planet Sci Lett 295:541-553. https://doi.org/10.1016/j.epsl.2010.04.029

Degruyter W, Bachmann O, Burgisser A, Manga M (2012) The effects of outgassing on the transition between effusive and explosive silicic eruptions. Earth Planet Sci Lett 349350:161-170. https://doi.org/10.1016/j.epsl.2012.06.056

Doocy S, Daniels A, Dooling S, Gorokhovich Y. The Human Impact of Volcanoes: a Historical Review of Events 1900-2009 and Systematic Literature Review. PLOS Curr Disasters 2013 Apr 16 . Edition 1.: https://doi.org/10.1371/currents.dis.841859091a706efebf8a30f4ed7a1901.

Druitt TH (2014) New insights into the initiation and venting of the Bronze-Age eruption of Santorini (Greece), from component analysis. Bull Volcanol 76:794. https://doi.org/10.1007/s00445-014-0794-x

Druitt TH, Edwards L, Mellors RM, et al (1999) Santorini Volcano. Geol Soc Mem 19:

Druitt TH, Mercier M, Florentin L, et al (2016) Magma Storage and Extraction Associated with Plinian and Interplinian Activity at Santorini Caldera (Greece). J Petrol 57:461-494. https://doi.org/10.1093/petrology/egw015

Flaherty T, Druitt TH, Tuffen H, et al (2018) Multiple timescale constraints for high-flux magma chamber assembly prior to the Late Bronze Age eruption of Santorini (Greece). Contrib Mineral Petrol 173:75. https://doi.org/10.1007/s00410-018-1490-1

Giachetti T, Druitt TH, Burgisser A, et al (2010) Bubble nucleation, growth and coalescence during the 1997 Vulcanian explosions of Soufrière Hills Volcano, Montserrat. J Volcanol Geotherm Res 193:215-231. https://doi.org/10.1016/j.jvolgeores.2010.04.001

Giordano D, Russell JK, Dingwell DB (2008) Viscosity of magmatic liquids: A model. Earth Planet Sci Lett 271:123-134. https://doi.org/10.1016/j.epsl.2008.03.038

Gonnermann HM, Manga M (2003) Explosive volcanism may not be an inevitable consequence of magma fragmentation. Nature 426:432-435. https://doi.org/10.1038/nature02138

Hajimirza S, Gonnermann HM, Gardner JE, Giachetti T (2019) Predicting Homogeneous Bubble Nucleation in Rhyolite. J Geophys Res Solid Earth 124:2395-2416. https://doi.org/10.1029/2018JB015891

Hamada M, Laporte D, Cluzel N, et al (2010) Simulating bubble number density of rhyolitic pumices from Plinian eruptions: constraints from fast decompression experiments. Bull Volcanol 72:735-746. https://doi.org/10.1007/s00445-010-0353-z 
613

614

615

616

617

618

619

620

621

622

623

624

625

626

627

628

629

630

631

632

633

634

635

636

637

638

639

640

641

642

643

644

645

646

647

648

Heiken G, McCoy F (1990). Precursory activity to the Minoan eruption, Thera, Greece. In: Hardy DA (ed.) Thera and the Aegean World III, vol 2. Thera Foundation, London, pp $13-18$.

Heiken G, McCoy F, Jr (1984) Caldera development during the Minoan eruption, Thira, Cyclades, Greece. J Geophys Res 89: 8441-8462

Hildreth W, Drake R (1992) Volcfin Quizapu, Chilean Andes. Bull Volcanol 54:93-125

Hooft EEE, Heath BA, Toomey DR, et al (2019) Seismic imaging of Santorini: Subsurface constraints on caldera collapse and present-day magma recharge. Earth Planet Sci Lett 514:48-61. https://doi.org/10.1016/j.eps1.2019.02.033

Houghton BF, Carey RJ, Cashman KV, Wilson CJ, Hobden BJ, Hammer JE (2010) Diverse patterns of ascent, degassing, and eruption of rhyolite magma during the 1.8 ka Taupo eruption, New Zealand: evidence from clast vesicularity. J Volcanol Geotherm Res 195:31-47.

Houghton BF, Carey RJ, Rosenberg MD (2014) The 1800a Taupo eruption: "III wind" blows the ultraplinian type event down to Plinian. Geology 42:459-461. https://doi.org/10.1130/G35400.1

Hurwitz S, Navon O (1994) Bubble nucleation in rhyolitic melts: Experiments at high pressure, temperature, and water content. Earth Planet Sci Lett 122:267-280. https://doi.org/10.1016/0012-821X(94)90001-9

Kaviris G, Papadimitriou P, Kravvariti Ph, et al (2015) A detailed seismic anisotropy study during the 2011-2012 unrest period in the Santorini Volcanic Complex. Phys Earth Planet Inter 238:51-88. https://doi.org/10.1016/j.pepi.2014.11.002

Klug C, Cashman KV (1996) Permeability development in vesiculating magmas: implications for fragmentation. Bull Volcanol 58:87-100. https://doi.org/10.1007/s004450050128

Liu Y, Anderson AT, Wilson CJN (2007) Melt pockets in phenocrysts and decompression rates of silicic magmas before fragmentation. J Geophys Res 112:B06204. https://doi.org/10.1029/2006JB004500

Lloyd AS, Ruprecht P, Hauri EH, et al (2014) NanoSIMS results from olivine-hosted melt embayments: Magma ascent rate during explosive basaltic eruptions. J Volcanol Geotherm Res 283:1-18. https://doi.org/10.1016/j.jvolgeores.2014.06.002

Mangan M, Sisson T (2000) Delayed, disequilibrium degassing in rhyolite magma: decompression experiments and implications for explosive volcanism. Earth Planet Sci Lett 183:441-455. https://doi.org/10.1016/S0012-821X(00)00299-5

Martel C, Iacono-Marziano G (2015) Timescales of bubble coalescence, outgassing, and foam collapse in decompressed rhyolitic melts. Earth Planet Sci Lett 412:173-185. https://doi.org/10.1016/j.epsl.2014.12.010 
Mason BG, Pyle DM, Oppenheimer C (2004) The size and frequency of the largest explosive 9

Massaro S, Costa A, Sulpizio R (2018) Evolution of the magma feeding system during a Plinian eruption: The case of Pomici di Avellino eruption of Somma-Vesuvius, Italy. Earth Planet Sci Lett 482:545-555. https://doi.org/10.1016/j.epsl.2017.11.030

Miller CF, Wark DA (2008) Supervolcanoes and their explosive supereruption. Elements 4:11-

Massol H, Koyaguchi T (2005) The effect of magma flow on nucleation of gas bubbles in a volcanic conduit. J Volcanol Geotherm Res 143:69-88. https://doi.org/10.1016/j.jvolgeores.2004.09.011

Mastin LG, Guffanti M, Servranckx R, et al (2009) A multidisciplinary effort to assign realistic source parameters to models of volcanic ash-cloud transport and dispersion during eruptions. J Volcanol Geotherm Res 186:10-21. https://doi.org/10.1016/j.jvolgeores.2009.01.008

Nishiwaki M, Toramaru A (2019) Inclusion of Viscosity Into Classical Homogeneous 15. https://doi.org/10.2113/GSELEMENTS.4.1.11

Mourtada-Bonnefoi CC, Laporte D (2004) Kinetics of bubble nucleation in a rhyolitic melt: an experimental study of the effect of ascent rate. Earth Planet Sci Lett 218:521-537. https://doi.org/10.1016/S0012-821X(03)00684-8

Myers ML, Wallace PJ, Wilson CJN, et al (2016) Prolonged ascent and episodic venting of discrete magma batches at the onset of the Huckleberry Ridge supereruption, Yellowstone. Earth Planet Sci Lett 451:285-297. https://doi.org/10.1016/j.epsl.2016.07.023

Myers ML, Wallace PJ, Wilson CJN, et al (2018) Ascent rates of rhyolitic magma at the onset of three caldera-forming eruptions. Am Mineral 103:952-965. https://doi.org/10.2138/am2018-6225 Nucleation Theory for Water Bubbles in Silicate Melts: Reexamination of Bubble Number Density in Ascending Magmas. J Geophys Res Solid Earth 124:8250-8266. https://doi.org/10.1029/2019JB017796

Pyle DM, Elliott JR (2006) Quantitative morphology, recent evolution, and future activity of the Kameni Islands volcano, Santorini, Greece. Geosphere 2:253. https://doi.org/10.1130/GES00028.1

Romine WL, Whittington AG (2015) A simple model for the viscosity of rhyolites as a function of temperature, pressure and water content. Geochim Cosmochim Acta 170:281-300. https://doi.org/10.1016/j.gca.2015.08.009

Shea T (2017) Bubble nucleation in magmas: A dominantly heterogeneous process? J Volcanol Geotherm Res 343:155-170. https://doi.org/10.1016/j.jvolgeores.2017.06.025 
Shea T, Houghton BF, Gurioli L, et al (2010) Textural studies of vesicles in volcanic rocks: An integrated methodology. J Volcanol Geotherm Res 190:271-289. https://doi.org/10.1016/j.jvolgeores.2009.12.003

Sigurdsson H, Carey S, Alexandri G, Vougioukalakis G, \& 10 others (2006) Marine

Taddeucci J, Wohletz KH (2001) Temporal evolution of the Minoan eruption (Santorini, Greece), as recorded by its Plinian fall deposit and interlayered ash ${ }^{-}$ow beds. J Volcanol Geotherm Res 19

Thomas N, Jaupart C, Vergniolle S (1994) On the vesicularity of pumice. Journal of Geophysical Research: Solid Earth, 99(B8), pp.15633-15644.

Toramaru A (2006) BND (bubble number density) decompression rate meter for explosive volcanic eruptions. J Volcanol Geotherm Res 154:303-316. https://doi.org/10.1016/j.jvolgeores.2006.03.027

Wilson L, Walker GPL (1987) Explosive volcanic eruptions - VI. Ejecta dispersal in plinian eruptions: the control of eruption conditions and atmospheric properties. Geophys J Int 89:657-679. https://doi.org/10.1111/j.1365-246X.1987.tb05186.x

Wilson, CJN, Houghton, BF (1990) Eruptive mechanisms in the Minoan eruption: evidence from pumice vesicularity. Thera and the Aegean world III, 2, 122-128.

Woods AW, Koyaguchi T (1994) Transitions between explosive and effusive eruptions of silicic magmas. Nature 370:641-644. https://doi.org/10.1038/370641a0

713

714

715

716

717

718

719

Zhang Y, Xu Z, Zhu M, Wang H (2007) Silicate melt properties and volcanic eruptions: SILICATE MELT PROPERTIES. Rev Geophys 45:. https://doi.org/10.1029/2006RG000216

720 et al. (2018) and references therein. 
(a) Map of Santorini and its host rift zone, showing major normal faults (circle on the hanging wall), and the three main subsidence basins. The extent of submarine ignimbrite from the LBA eruption mapped from seismic profiles is shown in yellow. A location map is included as inset.

(b) Map of Santorini caldera, showing the products of the LBA eruption (including the three main ignimbrite fans from eruptive phase 4), the outline of the shallow Cape Riva caldera that existed prior to the LBA eruption, the Kameni Line, and the approximate location of the Plinian vent.

729 Fig. 2 Field photos of the Plinian pumice fall deposit of phase $1(\mathrm{P} 1)$ of the eruption, with a meter stick represented in each photo. (a) The pumice fall deposit overlying breccias from an earlier eruption, and itself overlain by the bedded tuffs of phase 2. (b) The top of P1 showing the abundance of hydrothermally stained granitoid clasts at this level. (c,d) The P1 pumice fall deposit in southern Santorini where layer P1b is underlain by layer P1a, with a fine ash separating the two. The thin lapilli fallout of P0 lies at the bases of these outcrops. GPS locations for each site can be found in Supplementary Table 1 .

Fig. 3 Thickness and maximum lithic size data from 43 sample locations. (a-f) isopleth data (mean diameter in $\mathrm{cm}$ of three axes of the five largest lithic fragments in $1 \mathrm{~m}^{2}$ of each layer); (h-1) isopach data (cm). Figures (a) and (g) summarize the wind directions inferred from each technique. P0 wind direction taken from Cioni et al. (2000). The implied source vent for the eruption is shown by the black dot, matching that of Bonds and Sparks (1976).

Fig. 4 Photomicrographs of melt reentrants exposed in plagioclase (a-c) and pyroxene (d) crystals. All melt

Fig. 5 Simplified stratigraphy of the deposits from phases $0(\mathrm{P} 0)$ and $1(\mathrm{P} 1)$ of the eruption. Eight pumice samples (names shown in boxes) were taken from six layers (labelled in bold), with the lithic 
population percentages from Druitt (2014) shown as pie diagrams. Plume heights were calculated using the Carey and Sparks (1986) model from the isopleth data in Figure 3. Errors in plume height are based on uncertainties in isoline drawing. Plume heights were converted to mass eruption rate using the formula of Wilson and Walker (1987). Decompression rates (MPa s$\left.{ }^{-1}\right)$ are presented for melt reentrants (triangles), based on modeling of diffusion gradients preserved in plagioclase and pyroxene-hosted melt reentrants, and vesicle number densities (circles). Melt reentrant profiles were measured by FTIR spectroscopy at the University of Oregon (gray triangle), and by FTIR (open triangle) and Raman (black triangle) spectroscopy at the University of Clermont Auvergne. Vesicle number densities were converted to decompression rates using the formula of Toramaru (2006), based on the assumption of either heterogenous (gray circle) or homogenous (+ circle) vesicle nucleation. Error bars for melt-reentrant-based decompression rates are based on the

Fig. 6 Scanning electron microscope images, all taken at $\times 500$, of the eight pumice samples imaged, representing six layers of the pumice fall deposits; three pumice clasts are taken from layer P1b2.

\section{3}

Fig. 7 Concentration profiles for two separate melt reentrants, RDP 18 and RDP 20, both from P1a, measured for $\mathrm{H}_{2} \mathrm{O}$ profiles using three separate instruments. Each solid curve represents the bestThe glass is shown in white, and the vesicles in black on each image. Yellow scale in bottom right corner is $100 \mu \mathrm{m}$. fit decompression profile using the 1D diffusion model presented in Myers et al. (2018). UO: University of Oregon; UCA: University of Clermont Auvergne. For RDP 20, a fluorescent background characterizes the Raman spectra acquired at the extremities of this melt reentrant, resulting in slightly higher water contents estimated by Raman spectroscopy (see supplementary

770 Fig. 8 Schematic showing a snapshot in time of two possible explanations why the decompression rates recorded by melt reentrants are at least 2-3 orders of magnitude lower than those recorded by 
vesicle number densities. The figure shows two profiles through the LBA Plinian vent: (a) one perpendicular to the Kameni Line (profile A-B), and (b) the other parallel to it (profile C-D). The interpretation of each profile is as follows: (a) As magma ascends and degasses in the conduit, the viscosity (and hence pressure gradient) rises dramatically. Melt reentrants are thought to record the relatively low decompression rates $(\mathrm{dP} / \mathrm{dt})$ deep in the conduit, and vesicle number densities (VND) to record the high decompression rates associated with fragmentation. (b) An additional effect may have been that the eruption was fed through a dike along the Kameni Line, which then focussed into a cylindrical conduit at shallow levels. Due to upwardly converging flow, the decompression rates in the dike would have been slower than those in the shallow conduit.

782 Tables

783 Table 1: Descriptions of each of the six fallout layers and parameters calculated from lithic 784 isopleth maps.

785 Table 2: Vesicle size distribution parameters for each pumice clast analyzed.

786 Table 3: Information from individual reentrant profiles used to constrain decompression rates

787 using the 1D code described in Myers et al. (2018). $\mathrm{All}_{2} \mathrm{O}$ and $\mathrm{CO}_{2}$ measurements are based on 788 results from FTIR measurements at the University of Oregon (see Supplementary Table 6 for

789 results from the other techniques). For the diffusion model, starting pressure $(\mathrm{Pi}=165 \mathrm{MPa})$ and

790 initial $\mathrm{H}_{2} \mathrm{O}$ content (5.2 wt.\%) are based on the isolated melt inclusion data of Druitt et al.

791 (2016), where final pressure (Pf) is determined through the best-fit calculation. Conversion of

792 decompression rate $(\mathrm{dP} / \mathrm{dt}) \mathrm{t}$ to ascent rate assumes a magmastatic pressure gradient, a magma

793 density of $2600 \mathrm{~kg} \mathrm{~m}^{-3}$ and a magma fragmentation depth at $1 \mathrm{~km}$. 
Figures 1-8

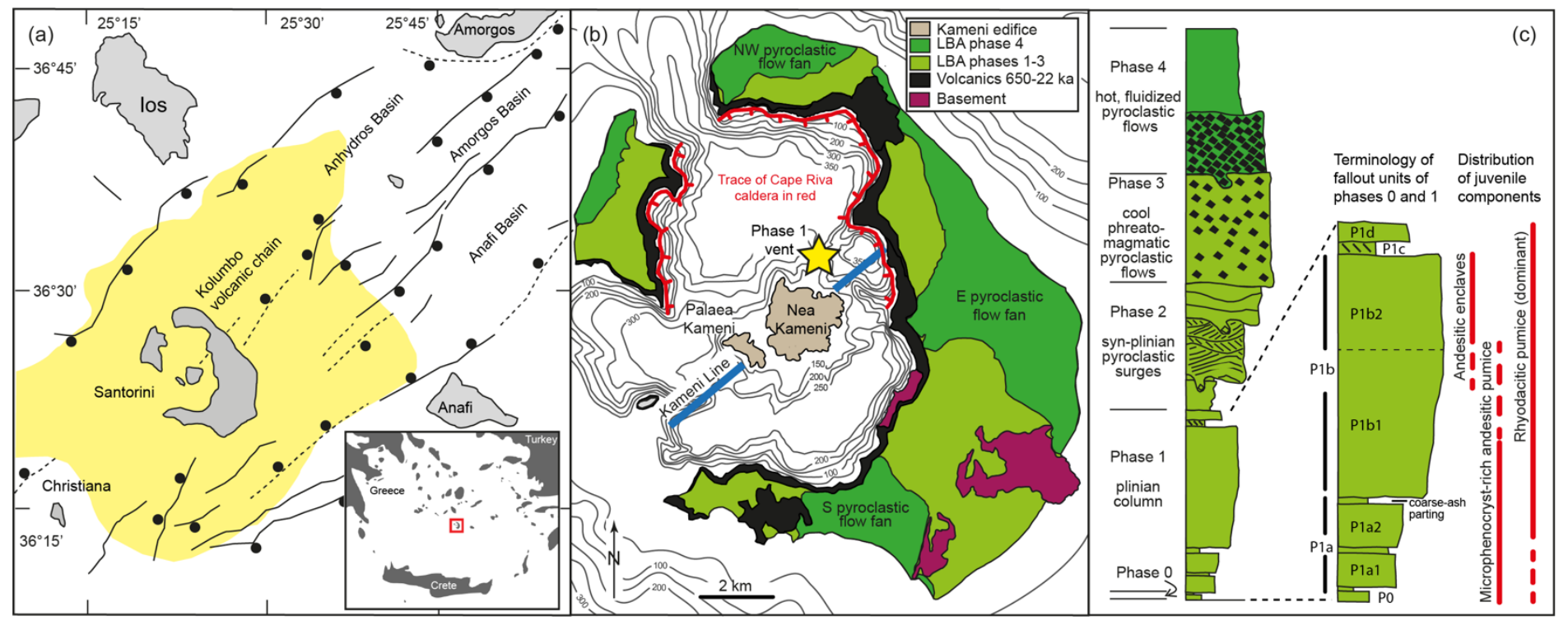

Fig. 1 


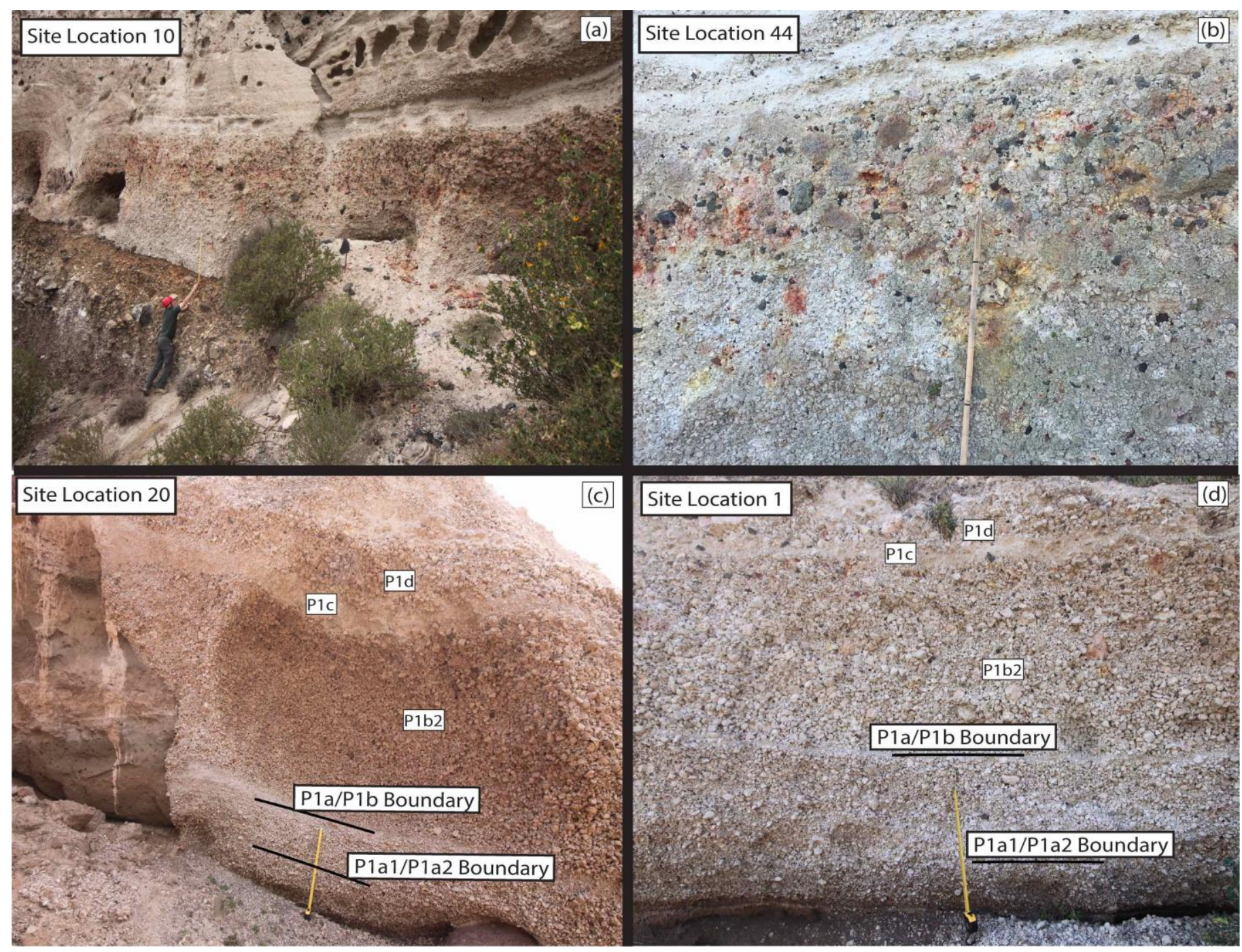

Fig. 2 


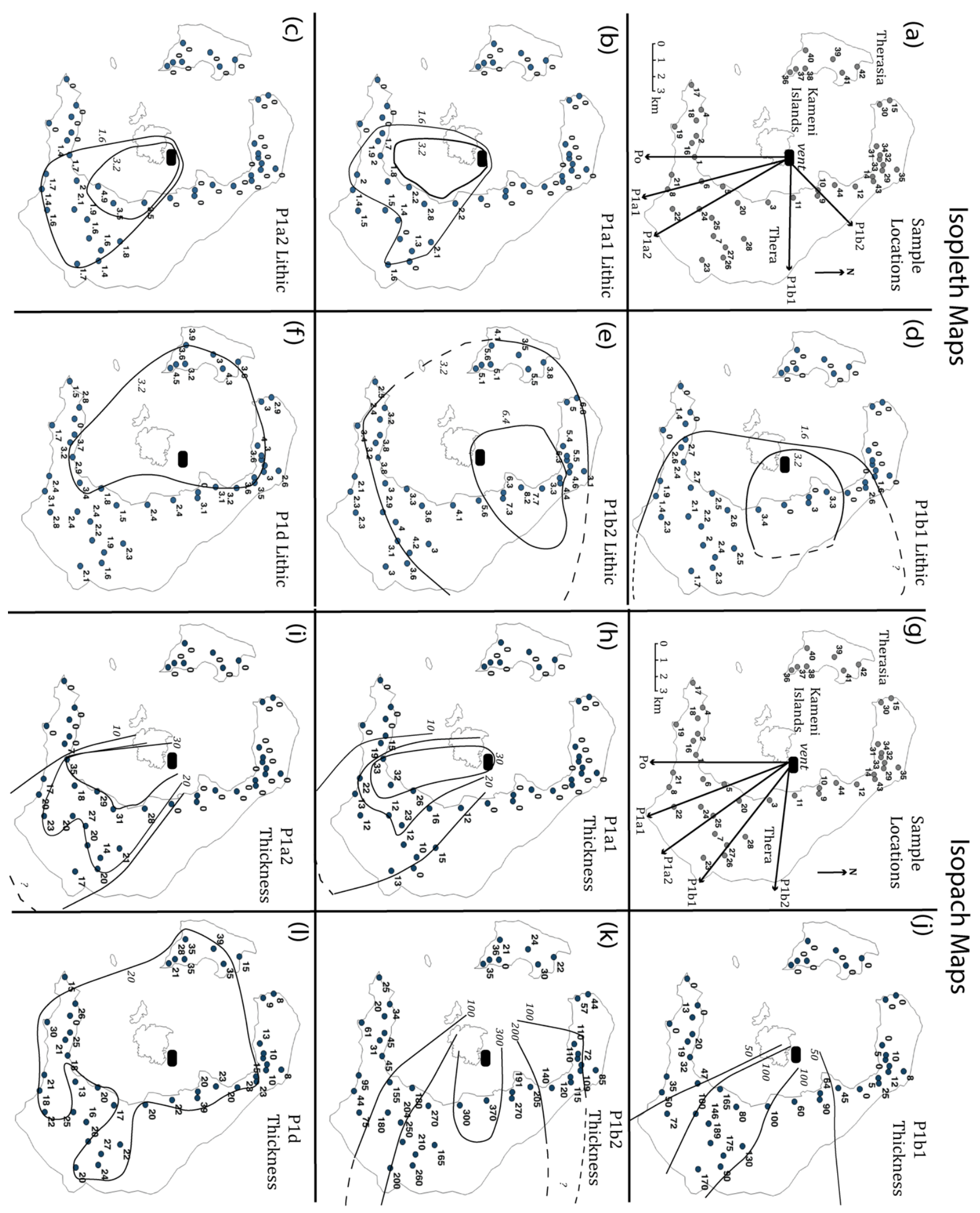

Fig. 3 


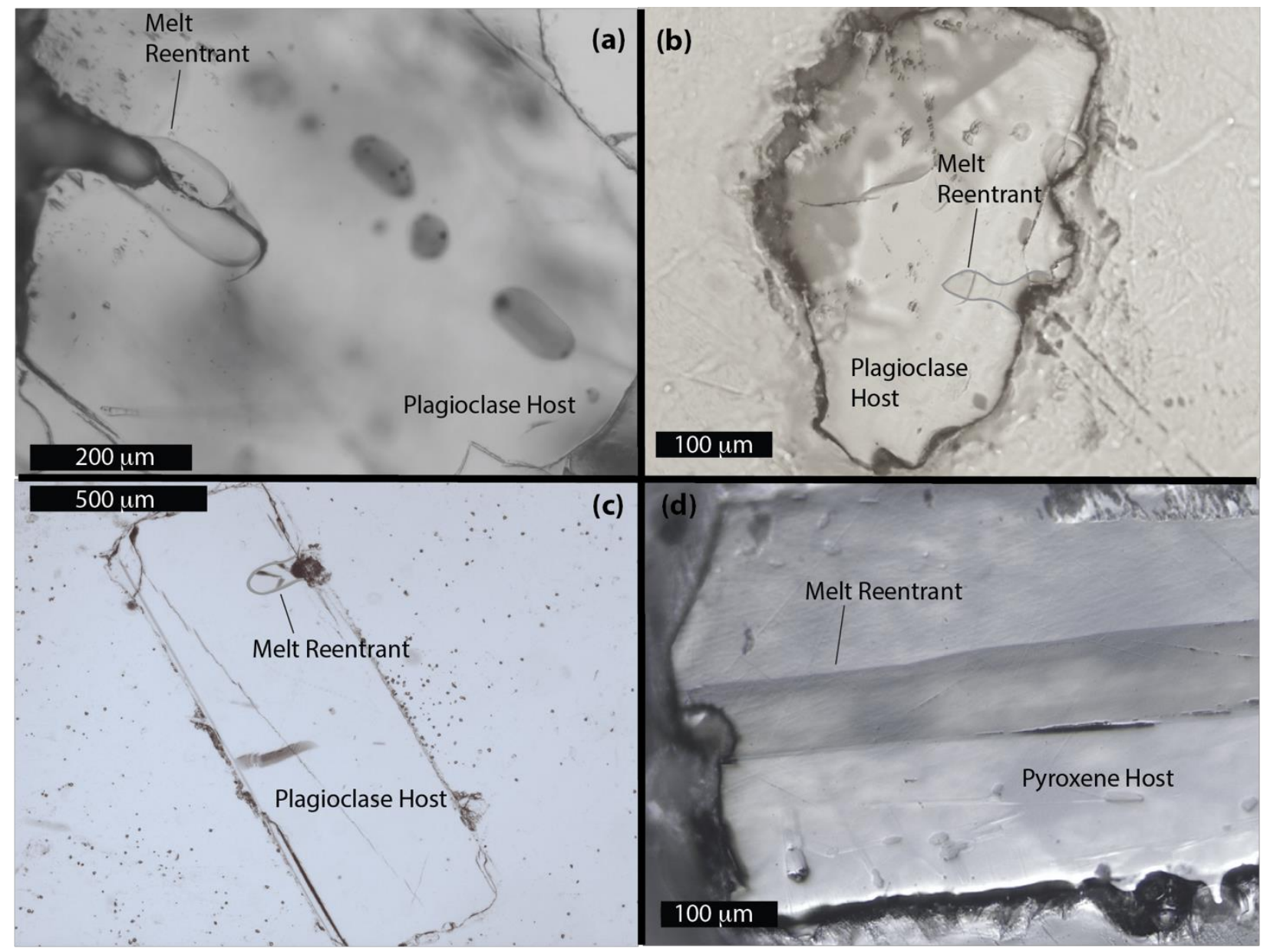

Fig. 4 


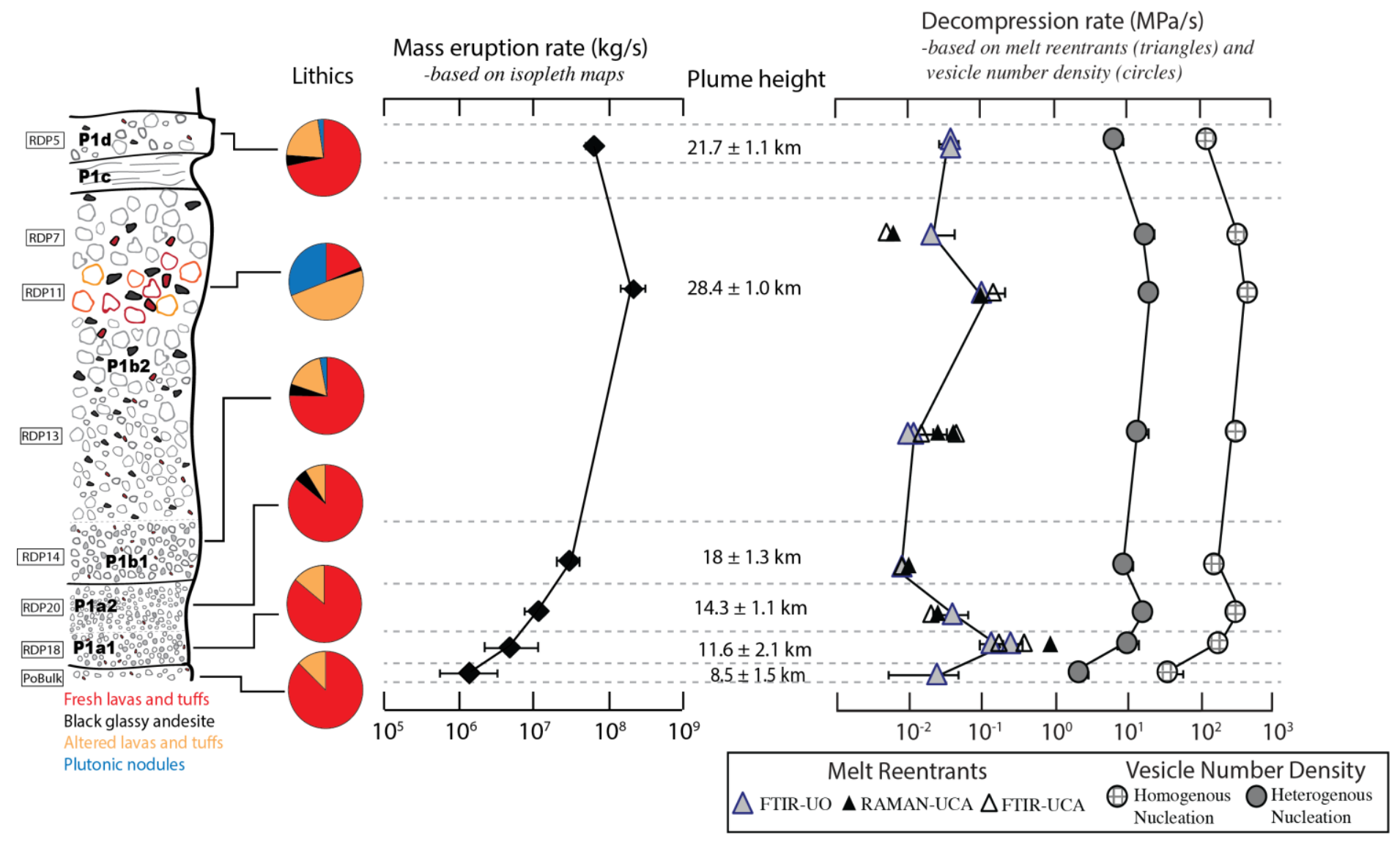

Fig. 5 

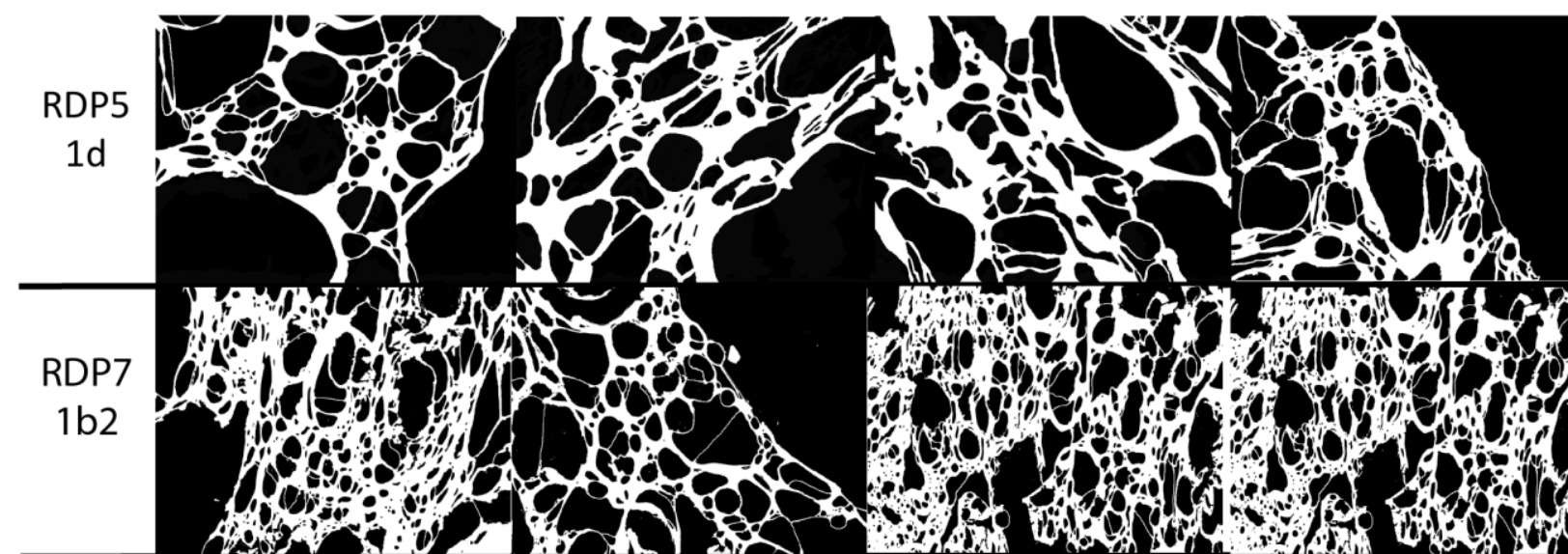

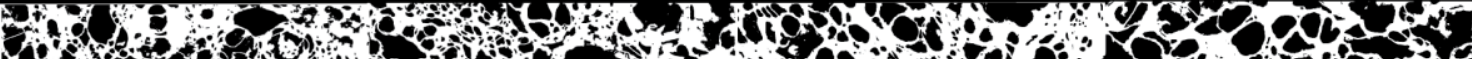

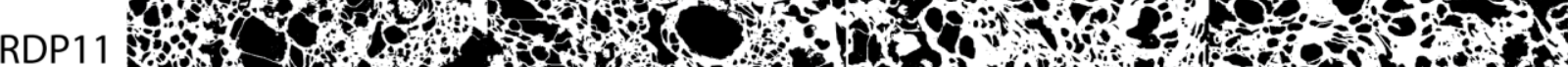

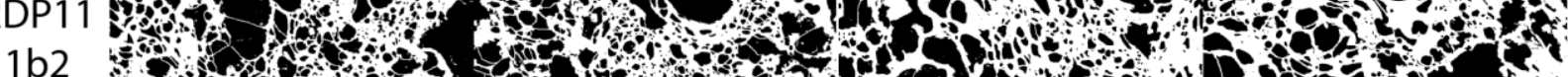

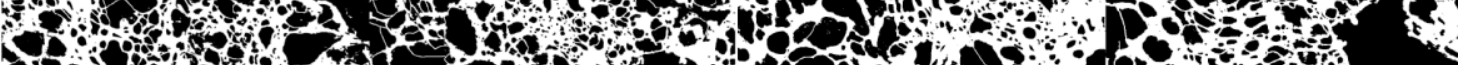

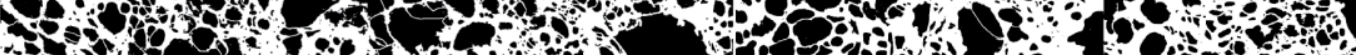

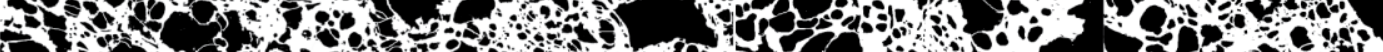

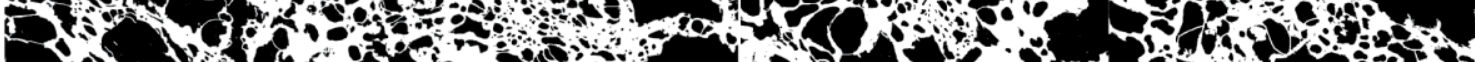

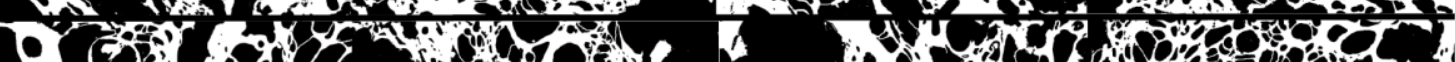
RDP13 rent

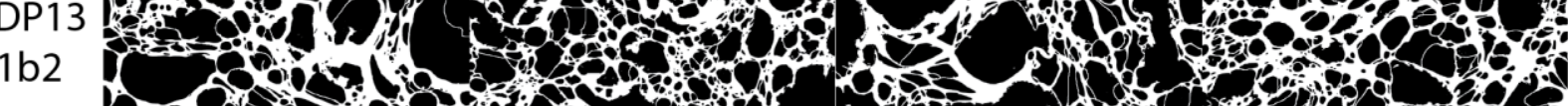

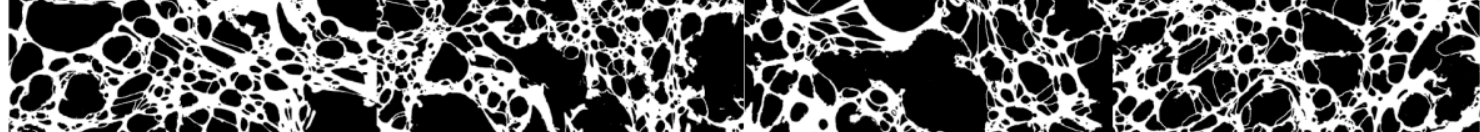

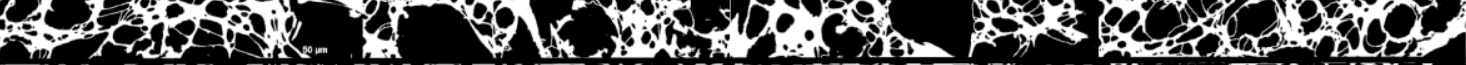

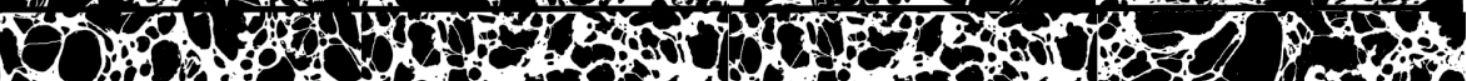

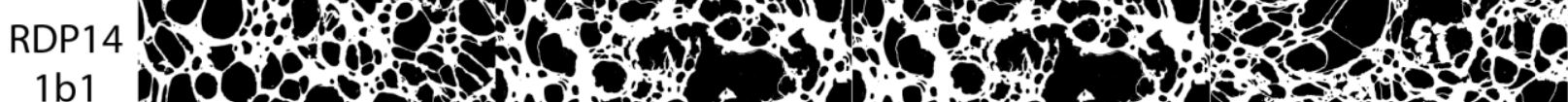

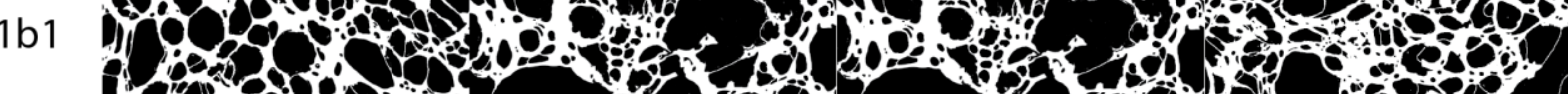

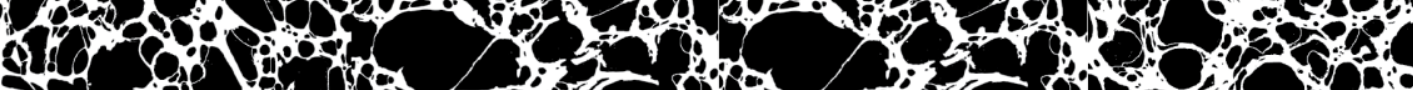

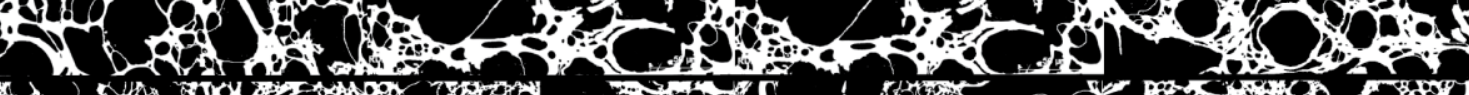

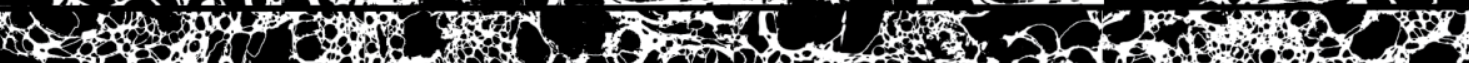

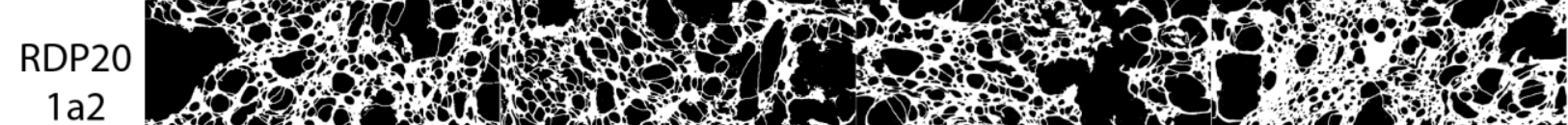

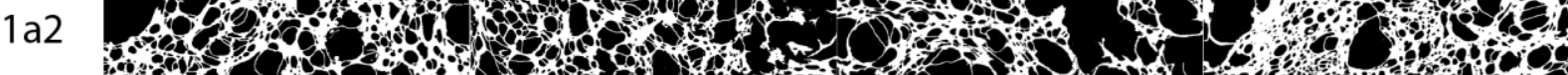

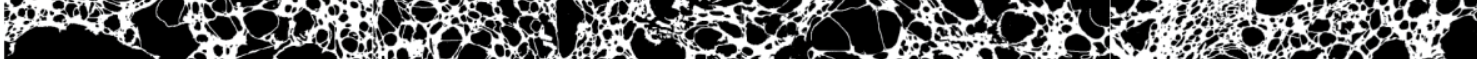

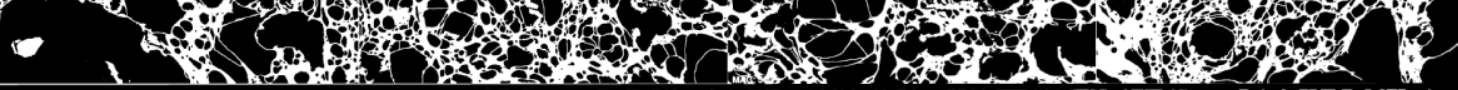

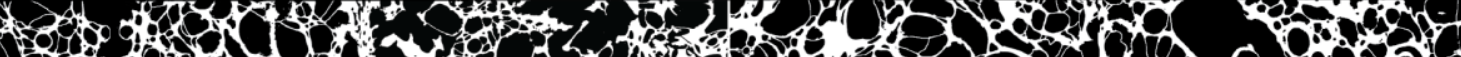

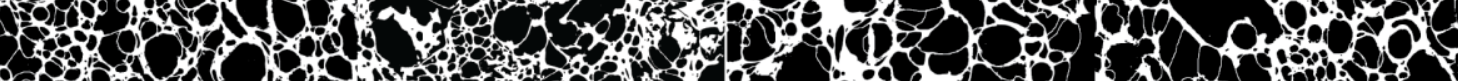

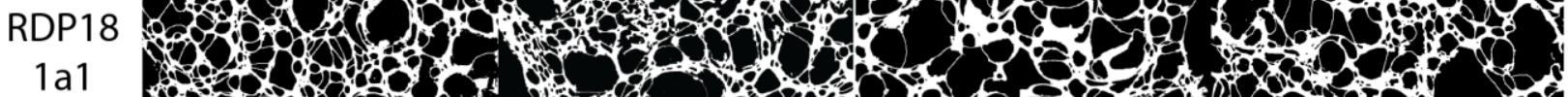

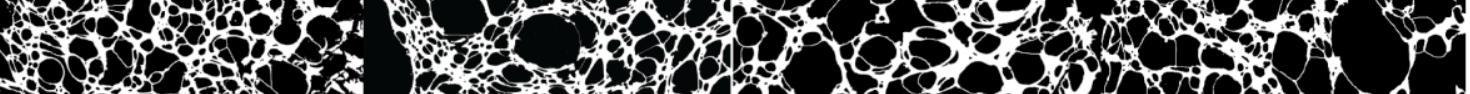

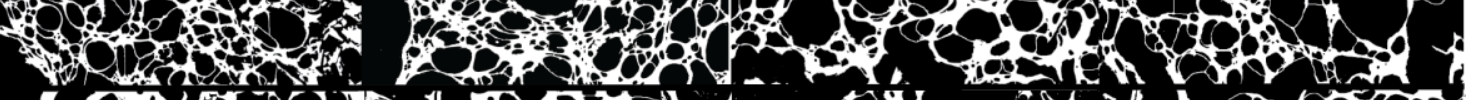

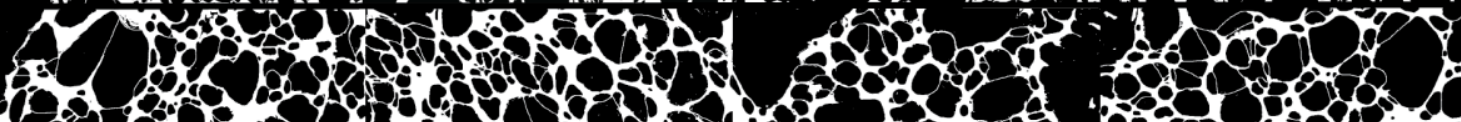
PoBulk 5 S

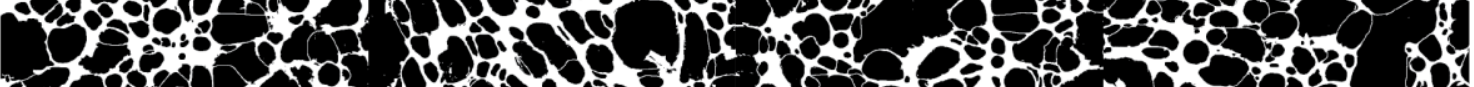

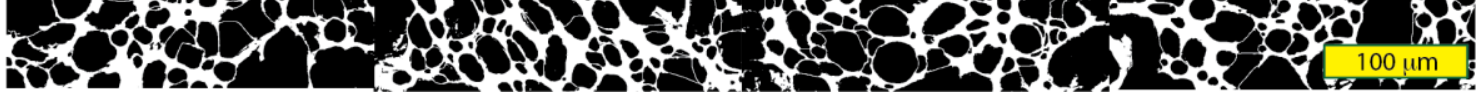

Fig. 6 
RDP20- RE 1

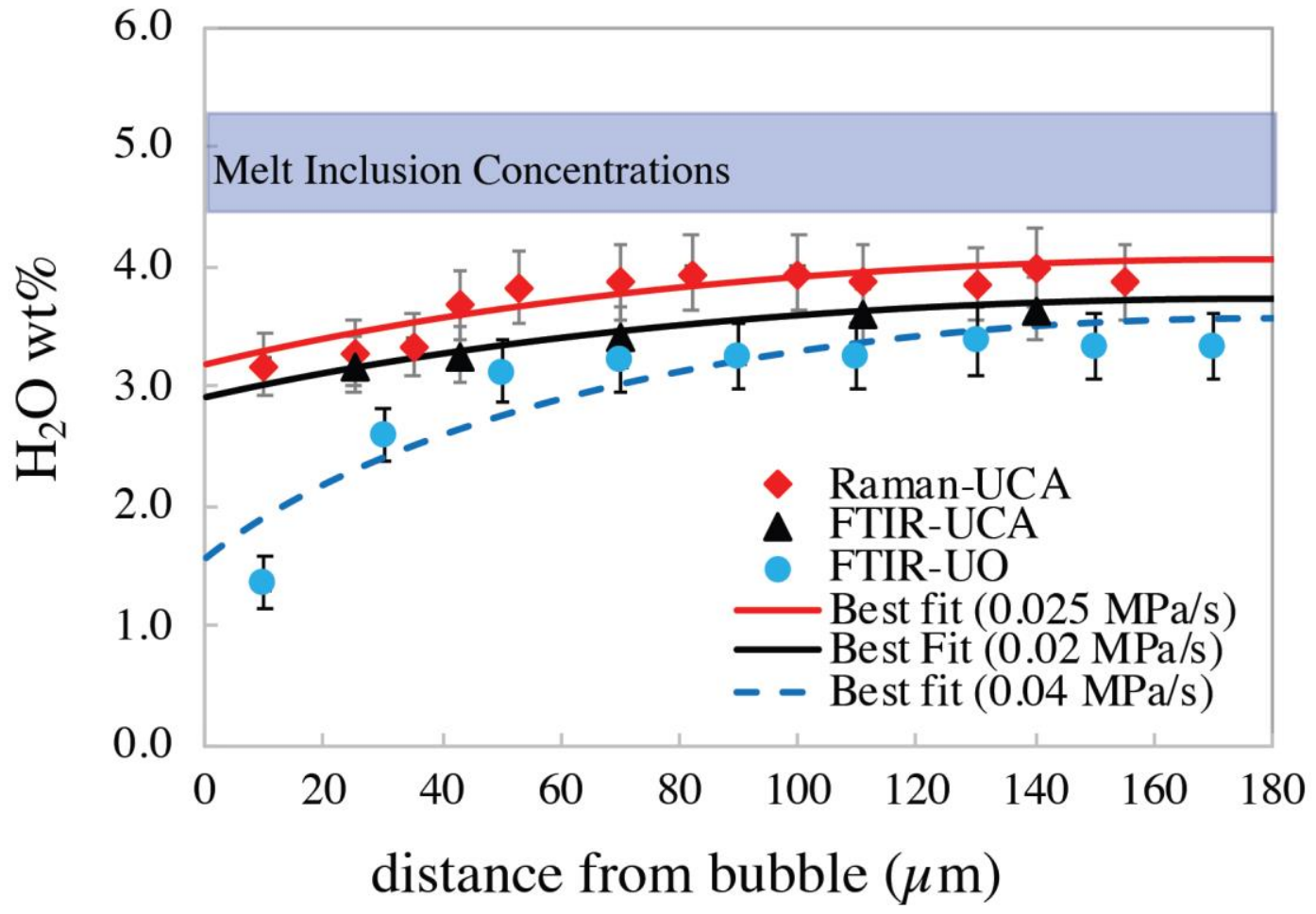

RDP18- RE 2

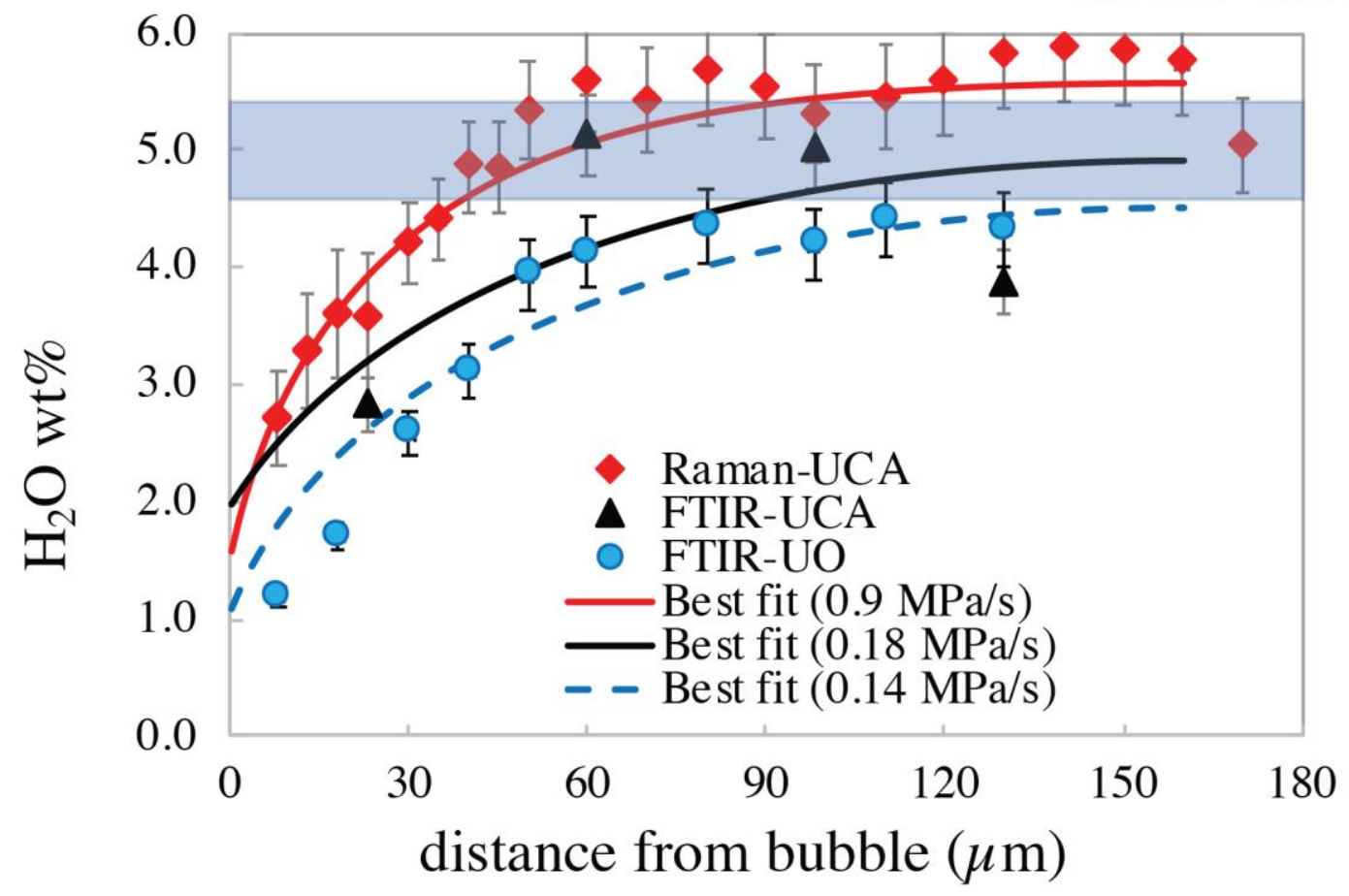

Fig. 7 


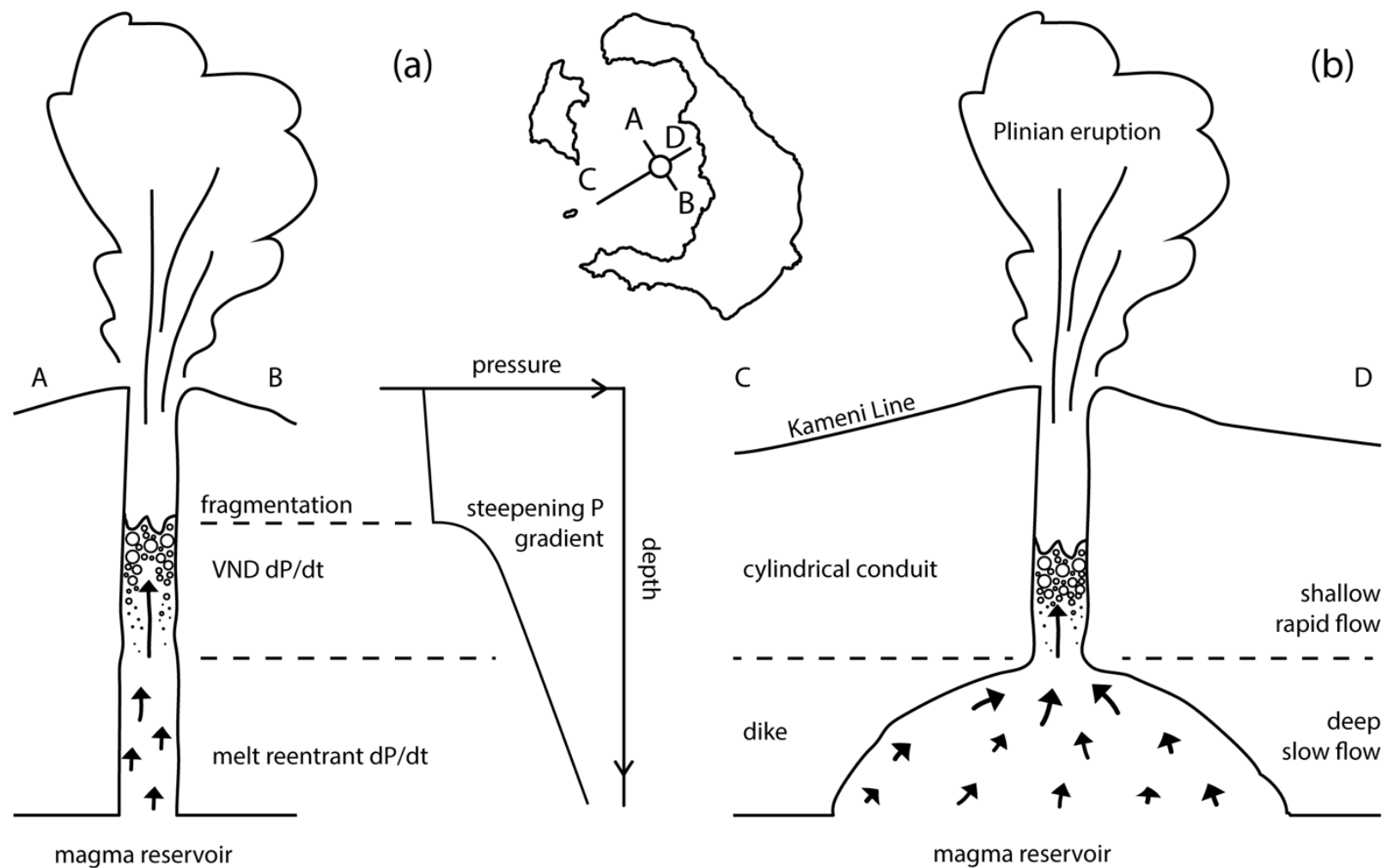

Fig. 8 


\section{Tables (1-3)}

Table 1:

\begin{tabular}{|c|c|c|c|c|c|}
\hline Layer & Characteristics & $\begin{array}{l}\text { Plume Height } \\
(\mathbf{k m})^{* 1}\end{array}$ & $\begin{array}{c}\text { Wind } \\
\text { Direction }\end{array}$ & $\operatorname{MER}(\mathrm{kg} / \mathrm{s})^{2}$ & $\operatorname{MER}(\mathrm{kg} / \mathrm{s})^{3}$ \\
\hline P0 & $\begin{array}{l}\text { Coarse ash fall with some } \\
\text { microphenocryst-rich } \\
\text { pumices. Beds A of Cioni et } \\
\text { al. (2000) }\end{array}$ & $8.5 \pm 1.5^{4}$ & $\mathrm{~S}$ & $1.7 \pm 1.2 \times 10^{6}$ & $1.0 \times 10^{6}$ \\
\hline P1a1 & $\begin{array}{l}\text { Lapilli pumice fall with } \\
\text { abundant microphenocryst- } \\
\text { rich pumices. Reversely } \\
\text { graded. Gray coloring. }\end{array}$ & $11.6 \pm 2.1$ & SSE & $5.8 \pm 3.9 \times 10^{6}$ & $3.7 \times 10^{6}$ \\
\hline $\mathrm{P} 1 \mathrm{a} 2$ & $\begin{array}{l}\text { Lapilli pumice fall with } \\
\text { abundant microphenocryst- } \\
\text { rich pumices. Two reversely } \\
\text { zoned layers. Gray coloring. }\end{array}$ & $14.3 \pm 1.1$ & SE & $1.3 \pm 0.4 \times 10^{7}$ & $8.8 \times 10^{6}$ \\
\hline P1b1 & $\begin{array}{l}\text { Pumice fall deposit with } \\
\text { whiter appearance. } \\
\text { Microphenocryst-rich pumices } \\
\text { scarce. }\end{array}$ & $18.0 \pm 1.3$ & $\mathrm{E}$ & $3.4 \pm 1.1 \times 10^{7}$ & $2.3 \times 10^{7}$ \\
\hline $\mathrm{P} 1 \mathrm{~b} 2$ & $\begin{array}{l}\text { Pumice fall deposit with white } \\
\text { appearance. Microphenocryst- } \\
\text { rich pumices scarce. } \\
\text { P1b1/P1b2 boundary marked } \\
\text { by incoming of rare cauliform } \\
\text { andesitic scoria. }\end{array}$ & $28.4 \pm 1.0$ & NE & $2.1 \pm 0.6 \times 10^{8}$ & $1.5 \times 10^{8}$ \\
\hline P1d & $\begin{array}{l}\text { Following pyroclastic surge } \\
\text { deposit (P1c), final pumice } \\
\text { fall layer before passage to } \mathrm{P} 2 \text {. }\end{array}$ & $21.7 \pm 1.1$ & $\begin{array}{l}\text { No } \\
\text { Wind } \\
?\end{array}$ & $7.2 \pm 1.3 \times 10^{7}$ & $5.0 \times 10^{7}$ \\
\hline \multicolumn{6}{|c|}{$\begin{array}{l}\text { *The plume height presented is determined using the } 3.2 \mathrm{~cm} \text { isopleth, assuming a lithic density of } 2500 \mathrm{~kg} / \mathrm{m}^{3} \text {, and calculated } \\
\text { using the plume inversion model of Carey and Sparks (1986), except for P0, where we used the value of Cioni et al. (2000). For } \\
\text { each layer, the minimum and maximum plume height was determined based on uncertainties in the cross and downwind ranges; } \\
\text { the average of this range is presented here along with the estimated uncertainty. Mass Eruption Rate (MER) was estimated using } \\
\text { the methods of Wilson and Walker (1987) and Mastin et al. (2009), and the uncertainty estimated for the Wilson and Walker } \\
\text { (1987) value. }{ }^{1} \text { Carey and Sparks (1986); }{ }^{2} \text { Wilson and Walker (1987); }{ }^{3} \text { Mastin et al. (2009); }{ }^{4} \text { Cioni et al. (2000). }\end{array}$} \\
\hline
\end{tabular}


Table 2:

\begin{tabular}{|c|c|c|c|c|c|c|c|c|}
\hline Sample & Location & Fall Layer & $\begin{array}{c}\text { Average } \\
\text { Vesicle } \\
\text { Diameter } \\
(\mu \mathrm{m})^{a}\end{array}$ & $\begin{array}{c}\mathrm{N}_{\mathrm{V}} \\
\left(\mathrm{mm}^{-3}\right)\end{array}$ & $\begin{array}{c}\mathrm{NV}^{b} \\
\text { corrected } \\
\left(\mathbf{m m}^{-3}\right)\end{array}$ & $\begin{array}{c}\mathrm{N}_{\mathrm{V}}^{\mathrm{c}} \\
\text { uncertainty } \\
\left(\mathrm{mm}^{-3}\right)\end{array}$ & $\begin{array}{l}\mathrm{dP} / \mathrm{dt} \mathrm{c}^{\mathrm{c}} \\
\text { Heterog } \\
(\mathrm{MPa} / \mathrm{s})\end{array}$ & $\begin{array}{l}\text { dP/dt } \\
\text { Homog. } \\
\text { (MPa/s) }\end{array}$ \\
\hline $\mathrm{P} 0$ & Location 1 & $\mathrm{P} 0$ & 13 & $6.24 \times 10^{5}$ & $2.50 \times 10^{6}$ & $7.58 \times 10^{5}$ & 2 & 50 \\
\hline RDP18 & Location 1 & Pla1 & 12 & $6.43 \times 10^{6}$ & $2.57 \times 10^{7}$ & $1.26 \times 10^{7}$ & 11 & 240 \\
\hline RDP20 & Location 1 & $\mathrm{P} 1 \mathrm{a} 2$ & 4 & $1.45 \times 10^{7}$ & $5.78 \times 10^{7}$ & $9.04 \times 10^{6}$ & 17 & 420 \\
\hline RDP14 & Location 11 & $\mathrm{P} 1 \mathrm{~b} 1 / \mathrm{P} 1 \mathrm{~b} 2$ & 9 & $5.37 \times 10^{6}$ & $2.15 \times 10^{7}$ & $5.94 \times 10^{6}$ & 9 & 220 \\
\hline RDP13 & Location 11 & $\mathrm{P} 1 \mathrm{~b} 2$ & 7 & $1.07 \times 10^{7}$ & $4.28 \times 10^{7}$ & $1.68 \times 10^{7}$ & 15 & 340 \\
\hline RDP11 & Location 11 & $\mathrm{P} 1 \mathrm{~b} 2$ & 5 & $1.64 \times 10^{7}$ & $6.56 \times 10^{7}$ & $1.50 \times 10^{7}$ & 19 & 450 \\
\hline RDP7 & Location 11 & $\mathrm{P} 1 \mathrm{~b} 2$ & 8 & $1.56 \times 10^{7}$ & $6.26 \times 10^{7}$ & $1.77 \times 10^{7}$ & 19 & 440 \\
\hline RDP5 & Location 11 & P1d & 9 & $3.42 \times 10^{6}$ & $1.37 \times 10^{7}$ & $4.16 \times 10^{6}$ & 7 & 160 \\
\hline
\end{tabular}

${ }^{a}$ Vesicle diameter is an average of the two axes.

${ }^{\mathrm{b}}$ Vesicle Number Density $\left(\mathrm{N}_{\mathrm{V}}\right)$ is corrected based on a vesicularity of $75 \%$, taken from Wilson and Houghton (1990).

${ }^{\mathrm{c}} \mathrm{N}_{\mathrm{V}}$ uncertainty is based on the 1 sigma SD of the Nv determined by analyzing each 500x image individually.

${ }^{\mathrm{d}}$ Magma decompression rates (dp/dt) were calculated from $\mathrm{N}_{\mathrm{V}}$ using the equations from Toramaru (2006), using assumptions of both heterogenous and homogenous nucleation. 
Table 3:

\begin{tabular}{|c|c|c|c|c|c|c|c|c|c|c|c|c|}
\hline $\begin{array}{c}\text { Melt } \\
\text { Reentrant } \\
\text { Name }\end{array}$ & $\begin{array}{c}\text { Fall } \\
\text { Layer }\end{array}$ & $\begin{array}{c}\text { Length of Melt } \\
\text { Reentrant } \\
(\mu \mathrm{m})\end{array}$ & $\begin{array}{c}\mathrm{H}_{2} \mathrm{O} \\
\text { Interior } \\
\text { (wt. } \%)\end{array}$ & $\begin{array}{c}\mathrm{CO}_{2} \\
\text { Interior } \\
(\mathrm{ppm})\end{array}$ & $\begin{array}{c}\text { Interior } \\
\text { Pressure } \\
\text { (MPa) }\end{array}$ & $\begin{array}{c}\mathrm{H}_{2} \mathrm{O} \\
\text { Mouth } \\
\text { (wt.\%) }\end{array}$ & $\begin{array}{c}\mathrm{CO}_{2} \\
\text { Mouth } \\
(\mathrm{ppm})\end{array}$ & $\begin{array}{c}\text { Pressure } \\
\text { Mouth } \\
\text { (MPa) }\end{array}$ & $\begin{array}{c}\text { dP/dt } \\
\text { Best fit } \\
(\mathrm{MPa} / \mathrm{s})\end{array}$ & $\begin{array}{c}\mathrm{dP} / \mathrm{dt} \\
\text { uncertainty } \\
(\mathrm{MPa} / \mathrm{s})\end{array}$ & $\begin{array}{c}\text { Ascent } \\
\text { Rate (m/s) }\end{array}$ & $\begin{array}{c}\text { Best Fit } \\
\text { Fragmentation } \\
\text { Pressure } \\
\text { (MPa) }\end{array}$ \\
\hline Po-1 & Po & 220 & 3.8 & 0 & 110 & 2.8 & 0 & 65 & 0.025 & 0.02 & 1.17 & 50 \\
\hline RDP18-1 & P1a1 & 90 & 4.3 & 0 & 119 & 2.9 & 0 & 61 & 0.25 & 0.1 & 11 & 40 \\
\hline RDP18-2 & P1a1 & 160 & 4.3 & 0 & 119 & 1.5 & 0 & 18 & 0.14 & 0.05 & 4.9 & 10 \\
\hline RDP20-1 & $\mathrm{P} 1 \mathrm{a} 2$ & 180 & 3.4 & 0 & 80 & 1.4 & 0 & 16 & 0.04 & 0.02 & 1.5 & 20 \\
\hline RDP14-4 & P1b1 & 320 & 3.2 & 0 & 72 & 2.31 & 0 & 40 & 0.008 & 0.001 & 0.3 & 30 \\
\hline RDP13-1 & $\mathrm{P} 1 \mathrm{~b} 2$ & 80 & 2.9 & 0 & 60 & 2.6 & 0 & 50 & 0.012 & 0.02 & 0.56 & 50 \\
\hline RDP13-5 & $\mathrm{P} 1 \mathrm{~b} 2$ & 80 & 1.9 & 0 & 28 & 1.67 & 0 & 23 & 0.01 & 0.01 & 0.37 & 20 \\
\hline RDP11-6 & $\mathrm{P} 1 \mathrm{~b} 2$ & 110 & 4.2 & 0 & 115 & 3.3 & 0 & 76 & 0.1 & 0.1 & 6.3 & 80 \\
\hline RDP7-5 & $\mathrm{P} 1 \mathrm{~b} 2$ & 140 & 4.3 & 0 & 119 & 3.8 & 0 & 97 & 0.02 & 0.02 & 1.43 & 90 \\
\hline RDP5-1 & P1d & 170 & 3.8 & 0 & 97 & 2.8 & 0 & 57 & 0.035 & 0.01 & 1.79 & 60 \\
\hline RDP5-2 & P1d & 90 & 2.4 & 0 & 43 & 1.8 & 0 & 26 & 0.035 & 0.01 & 1.3 & 20 \\
\hline
\end{tabular}




\section{Click here to access/download Supplementary Material SUPPLEMENT LAB-2020_Dec.docx}


Click here to access/download Supplementary Material Supplemental Tables Decompression DEC 2020.xlsx 